\title{
O Melhor Amigo do Rei. A imagem da perfeita privanza na Monarquia Hispânica do século XVII ${ }^{1}$ \\ Ricardo de OLIVEIRA ${ }^{\bullet}$
}

Resumo: A controversa personagem do valido ou privado foi motivo de inúmeras polêmicas durante o século XVII no âmbito da Monarquia Hispânica, principalmente no contexto dos Reinados de Felipe III e Felipe IV. Diversos autores debruçaramse sobre o tema para atacar a figura do favorito, enquanto inúmeros outros defenderam a sua legitimidade como devotados amigos do rei, a ajudá-lo na condução dos negócios do Império. Inerente a esse fenômeno, deu-se a criação do gênero literário denominado Espelho de Privanza. Este artigo pretende interrogar o sentido de algumas destas construções positivas do valimento no âmbito do pensamento político espanhol do século XVII.

Palavras-Chave: Valimento; Monarquia Hispânica; Pensamento Político.

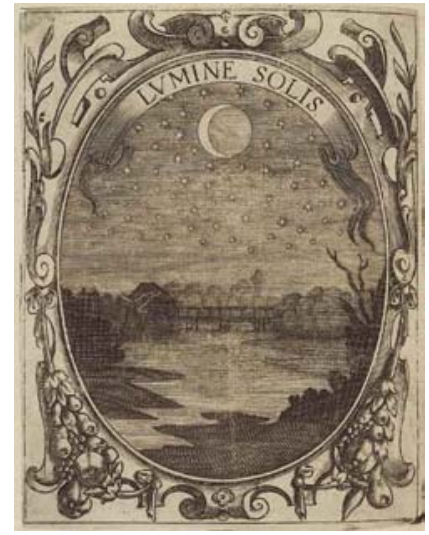

- Professor Doutor - Departamento de História - Programa de PósGraduação em História - UFRRJ - Universidade Federal Rural do Rio de Janeiro - 23890-000 - Rio de Janeiro - RJ - Brasil. E-mail: rdoclio@ufrri.br 
Em importantes passagens de sua obra maior, Idea de un Príncipe político Christiano, Representada en cien Empresas ${ }^{2}$, impressa pela primeira vez em 1640 e de considerável repercussão na época, o influente pensador espanhol, Don Diego de Saavedra Fajardo (1584-1648), dedicou-se à analise do fenômeno dos validos na política européia do período. A quadragésima nona empresa apresenta um emblema cuja mensagem não poderia ser mais alusiva à presença do valimento na esfera central do poder nas grandes monarquias ${ }^{3}$. Lumine Solis é o mote interno ao emblema e pode ser traduzido da seguinte maneira: da luz do sol, a lua retira toda a sua luminosidade, pois não possui luz própria. E no início da glosa que acompanha o emblema explica-se que em meio a um céu estrelado, numa imagem panorâmica que nos remete à amplitude do palato, brilha a lua na fase de quarto minguante. $O$ astro representa a própria imagem do valido, que brilha desprovido de luz própria, retirando seu fulgor, autoridade e arbítrio do príncipe - personagem reiteradas vezes associado, no período, principalmente na monarquia francesa sob o reinado de Luis XIV, a representações simbólicas do astro maior, o sol ${ }^{4} . \mathrm{Na}$ verdade, Fajardo, a quem retornaremos à frente de forma mais detida, testemunhava a força desse prodígio sentido em todo o velho continente, com maior destaque nas grandes monarquias, isto é, a política européia estava, conforme dizia o pensador, nas "mãos de validos" . E sobre a amplitude do fenômeno, Fajardo anotaria mais à frente o seguinte: "Bien testifican los ejemplos pasados, acreditados con los presentes,, derribados en nuestra edad los mayores validos del mundo: en España el duque de Lerma, en Francia el marisca de Ancre, en Inglaterra el duque de Boquingan, en Holanda Juan Olden Vernabelt, en Alemania el cardenal Cliselio, en Roma el cardenal Nazaret".6. Em suma, no grande teatro de lutas e conflitos que marcaram a história na época, em que a Guerra dos Trinta Anos era o evento mais dramático, momento crucial para a afirmação das monarquias modernas, o poder de fato, a realpolitik e os mecanismos da Razão de Estado eram, senão conduzidos, ao menos influenciados por esse personagem singular ${ }^{7}$. 
Outro importante pensador da época, Francis Bacon (15611626), que fora ele mesmo amigo e protegido de favoritos régios como Robert Devereux (Conde de Essex), Georges Villiers (10. Duque de Buckingham) e Tobby Matthew, afirmara pouco tempo antes que a maioria dos Príncipes do seu tempo procurava superar as angústias, os sufocamentos, os desgostos e as desesperanças recorrendo ao conforto de um amigo especial. Segundo Bacon, estes, conhecidos nas línguas vernáculas modernas como privados ou favoritos, seriam de forma mais apropriadamente designados por participes curarum - que significa participar dos cuidados ou inquietações que se acometiam aos Príncipes. Prova disso era que entre essa classe de súditos e o Príncipe estabelecia-se um tipo de amizade fortíssima, pois era concedido ao privado participar dos negócios mais graves do reino. Príncipes fortes e fracos recorriam a esses amigos, favorecendo-os com muitas e merecidas graças ${ }^{8}$.

Bem, esses dois testemunhos apontam para a importância que a temática do valimento ocupava no debate intelectual da época. Ou seja, de forma mais objetiva, podemos dizer que o tema esteve presente de maneira significativa no pensamento político europeu, com intensidade notável na Península Ibérica do século XVII, pois lá se constituiu, por assim dizer, em verdadeiro topos discursivo intrinsecamente relacionado à realidade política da Monarquia Hispânica. Fosse para atacar até mesmo reprovar por completo a presença desse personagem junto à esfera central do poder - ou, justamente com a intenção oposta, legitimar ou exaltar o valimento ou algum favorito em particular, o tema suscitara polêmicas. Para se ter uma idéia sobre a amplitude que o tema alcançou, lembremos que no teatro barroco do Século XVII, notadamente em Inglaterra e Espanha, o fenômeno do favoritismo régio suscitou o estabelecimento de um gênero de dramaturgia específico conhecido como Comedia de la Privanza, estruturado a partir do argumento narrativo em torno da ascensão e queda - la prospera y la adversa fortuna - de algum personagem identificado como valido ou privado ${ }^{9}$. Enfim, filósofos, teólogos, poetas e letrados de uma forma geral dedicaram parte de suas respectivas 
reflexões para discutir a questão dos validos como problema relativo à própria constituição do poder monárquico ${ }^{10}$. Em obra intitulada Theatro Monarchico de España que contiene las mas puras, como Catholicas máximas de Estado, por las quales, assi los Príncipes, como las Republicas aumentan, y mantienen sus Domínios, y las causas que motivan su ruyna, escrita na última década do século XVII, de suma importância para o correto entendimento, em seu conjunto, dos aspectos básicos do pensamento político espanhol del siglo de oro, pois é uma verdadeira síntese de idéias e teses bastante recorrentes e aceitas pelos escritores que lhe precederam, bem como um balanço crítico dos rumos da monarquia, Pedro Portocarrero y Guzmán (1645?-1708), apesar de se posicionar criticamente perante ao valimento, dizia que em virtude da presença "natural" do valido na cena política e social, era inevitável que a questão houvesse feito aumentar o volume dos livros destinados a tratar de assuntos políticos, não existindo personalidade política que não tivesse que refletir sobre a questão, pois dela dependia tanto o aumento quanto a ruína das monarquias ${ }^{11}$.

O fenômeno do valimento, portanto, pode oferecer acesso privilegiado ao importante debate em torno dos fundamentos do poder e da própria instituição monárquica no Antigo Regime. Pretendemos problematizar as dimensões deste fenômeno no âmbito do discurso político do Antigo Regime, mais especificamente no contexto da Península Ibérica. Conviveram, lado a lado, no campo particular do pensamento político, juízos extremamente negativos e, ao mesmo tempo, verdadeiras defesas apologéticas acerca da presença de privados junto ao rei, no interior da vida política das Cortes em que o fenômeno se fazia sentir. Na busca de legitimar o valimento no âmbito do governo da monarquia, vários recursos intelectuais foram empenhados, por vezes repetitivamente. Tomando a história como magistrae vitae, crença alargada na época em diversos contextos intelectuais, os exemplos do passado eram amplamente utilizados para fazer acreditar que, sendo bom o valido, seu valimento seria importante para a vida do Reino, pois 
aliviaria o rei dos mais pesados fardos, tornando-se escudo e pilar para a boa governação.

Deste modo, objetivando acima de tudo contribuir com as investigações que nos últimos anos têm lançado novas luzes sobre essas dimensões centrais da História do Pensamento Político do Antigo Regime, neste artigo discutiremos, por assim dizer, o sentido positivo de algumas construções intelectuais surgidas no período com o objetivo de legitimar a presença dos validos no âmbito da monarquia hispânica do século XVII. A literatura política de caráter prescritiva destinada a outros personagens da vida áulica como secretários, conselheiros e embaixadores, apesar de intrinsecamente relacionada à questão do valimento, não será o foco de nossa análise. Ater-nos-emos privilegiadamente à análise de um conjunto de discursos notadamente os Espelhos de Privanza - que serviram de veículo para a construção de um sofisticado produto intelectual, isto é, a idéia de perfeito privado cristão - modelo de conduta para o exercício da privanza no pensamento político espanhol da época. Procuraremos decifrar como esses autores conceberam de certa maneira uma ontologia do valimento. Suas origens históricas, sua natureza e as razões de sua necessidade intrínsecas à realidade da monarquia hispânica. Assim, buscamos compreender as representações e os símbolos relacionados às virtudes ${ }^{12}$. qualidades e adjetivos que, efetivamente, formavam o retrato do valido ideal.

O tacitista Juan Alfonso de Lancina (1649-1703), nos Commentarios Políticos a los Annales de Cayo Cornélio Tácito, obra publicada em 1687, afirmava taxativamente que "deben tener los príncipes algún amigo íntimo con quien confiarse" ${ }^{13}$. Ou seja, tratava-se da necessidade do melhor amigo a quem o rei pudesse se valer. Não obstante, traçar a genealogia do processo simbólico de positivação dos conceitos de valido ou privado no vocabulário político dos pensadores espanhóis da primeira 
modernidade é uma tarefa revestida de complexidade. Os indícios mais consistentes da luta simbólica que permitiu a legitimação do valimento, enquanto prática necessária e inerente à realidade da monarquia hispânica, localizam-se no final do século XVI, momento em que começaram a expandir teses que explicitamente faziam à defesa dos validos, embora o livro Aviso de Privados ${ }^{14}$, do Fray Antonio de Guevara (14801545), publicado pela primeira vez em 1539, possa até ser considerado um marco fundador, pois antecipou em quase um século determinados elementos que serão comuns ao gênero dos Espelhos de Privanza devido ao seu conteúdo prescritivo de ensinar como deveria se comportar o privado no ambiente áulico. Porém, na verdade, tal como outras semelhantes escritas na época, como Il Cortegiano, de Baladassare Castiglione (14781529) ${ }^{15}$, e Galateo ou dos Costumes, de Giovanni Della Casa $(1503-1556)^{16}$, esta obra deve ser compreendida como um esforço no sentido de doutrinar a conduta dos indivíduos que pretendessem vivenciar a experiência radical da vida cortesã, ao tempo em que se acelera o processo de "controle" sobre a nobreza, algo sempre incompleto, ainda não existia uma reflexão sobre o papel desse sujeito no universo palaciano enquanto real protagonista da governação do reino.

Outro vestígio relevante apareceria alguns anos mais tarde. Na Summa de Tratos y Contratos, de 1569, do Dominicano Tomás de Mercado (?-1575), a questão do valimento apareceu de forma interessante. Discorrendo sobre o papel central da amizade e do amor como elementos reguladores das relações "econômicas", a partir daquilo que Bartolomé Clavero nomeou agudamente por antidora ${ }^{17}$, enquanto conceito explicativo para uma antropologia política da economia moderna, Mercado dizia que "es licito procurar mediante el préstimo la privanza o familiaridad de algún príncipe o prelado, para que despues por amor y valor, no por interes ni pacto, le dé lo que pretende y dessea..." ${ }^{18}$. Na visão do Dominicano, a legitimidade da privanza dar-se-ia na medida em que os elementos reguladores da relação do privado com seu príncipe protetor fossem fundados na perfeita amizade e amor, sem vínculos de interesse formalizados 
em contratos e sem a perspectiva das vantagens individuais. Pouco tempo depois, em uma das passagens de sua Miscelánea o Varia Historia, escrita em 1589, Luis Zapata de Chaves (15261595), personagem que conviveu na Corte de Felipe II, recordava que o Imperador Carlos $\mathrm{V}$ teve privados, isto é, pessoas a quem concedia graças devido ao fato de lhe serem de muita valia na condução dos duros negócios de seu Império Universal ${ }^{19}$.

Todavia, curiosamente a primeira explícita defesa do valimento, enquanto legítimo e necessário artifício para a boa governação do reino, surgiu onde menos se poderia esperar: no discurso neo-escolástico. Em geral, os pensadores que se identificavam com essa "doutrina", como os jesuítas Juan Mariana (1536-1624), Pedro de Ribadeneyra (1526-1611) e Francisco Suarez (1548-1617), realizaram severas críticas ao valimento. Mas, um legítimo representante do pensamento neoescolástico, de profunda inspiração tomista, o Agostiniano Fray Marco Antonio de Camos y Requesens (1545-1606), na obra Microcosmia y Gobierno Universal del Hombre Christiano, para todos los estados y qualquier de ellos, publicada em 1592, fez enfática defesa da presença do privado como elemento fundamental eleito pelo Rei para "su servicio, para la administracion de sus reinos, y para allegarlos a sí y encagarles el inestimable tesoro de su real persona". Camos descreve que o privado deveria ser homem virtuoso porque seria ele o responsável por apresentar ao Rei "los negócios, las consultas y lo resuelven todo en lo secreto con él"20. Assim, apesar das semelhanças que possam existir entre as ideias de Camos e os matizes centrais do pensamento neo-escolástico - por exemplo, no que tange à defesa do contratualismo e à crítica ao absolutismo -, o agostiniano era rigorosamente favorável à presença dos validos junto à cabeça da república. Todavia, o processo através do qual a idéia de valimento veio a ser legitimada e incorporada ao escopo do pensamento neoescolástico não é fácil de precisar em toda a sua amplitude, pois, na maioria dos casos, a crítica ao valimento foi tópico recorrente entre esses pensadores, relacionada muitas vezes ao antimaquiavelismo ${ }^{21}$. 
Destarte, era extenso o universo discursivo em que a questão estava inserida. Mas, a partir de agora, focaremos nossa atenção de forma privilegiada nos Espelhos de Privanza, gênero literário criado como uma resposta direta à irrupção e institucionalização do fenômeno do valimento a partir do final do século XVI, atingindo o ponto culminante durante o século seguinte, com os valimentos de Don Francisco Gomez de Sandoval y Rojas, Duque de Lerma ${ }^{22}$, Don Gaspar de Guzman e Conde Duque de Olivares $^{23}$. Intrinsecamente relacionado ao gênero maior dos Specula Princips (Espelhos de Príncipe) ${ }^{24}$, cuja longuíssima tradição remete-nos a autores da antiguidade clássica e da tradição cristã medieval como Xenofonte, Sêneca, Santo Agostinho, São Tomás de Aquino, Egidio Romano ${ }^{25}$; os Espelhos de Privanza, estruturados a partir desse modelo fundador, propunham-se a ser verdadeiros manuais prescritivos para a boa conduta no universo áulico e nas questões relacionadas ao governo do reino. Esses escritos tinham também como estratégia de afirmação editorial, inclusive, a intenção de justificar o valimento como parte integrante do corpo da monarquia e sua importância para o bom governo do reino. A importância desses textos é muito mais relevante porque foram escritos no momento em que vigorava, e tinham inexoravelmente alguma conexão como alguma estratégia de propaganda e legitimação de algum valido. Assim sendo, destaquemos que, no processo de construção da imagem do perfeito privado cristão, invariavelmente, os autores com os quais estamos lidando oscilavam entre representações oriundas de modelos clássicos e bíblicos na forma de simbolizar tanto o desejável quanto o indesejável valimento.

O primeiro documento a que necessariamente devemos nos reportar é a missiva intitulada $A$ un Gran Privado (1594), escrita pelo secretário de Felipe II, Antonio Perez (1540?-1611), notável personagem que vivenciou intensamente as agruras do mecanismo social da privanza na Monarquia Hispânica ${ }^{26}$. Nessa carta, Perez procurava definir a própria natureza da privanza e a melhor estratégia que se deveria ter para alcançar e se manter sob a graça do príncipe ${ }^{27}$. Porém, foi no período imediatamente 
posterior ao eclipse do secretário António Perez, quando se conheceu a hegemonia dos respectivos valimentos do Duque de Lerma e do Conde-Duque de Olivares, que podemos identificar a grande proliferação desse gênero literário, tanto na forma impressa quanto manuscrita, no contexto cultural da Monarquia Hispânica. O Discurso del Perfecto Privado, de Fray Pedro de Maldonado, obra escrita em 1609 e dedicada ao Duque de Lerma, pode ser pensado como o primeiro modelo efetivo de Espelho de Privanza, apesar de não ter sido publicada e circular apenas em cópias manuscritas, fenômeno não incomum na época ${ }^{28}$. Para Maldonado, de certa maneira, o valimento estava inscrito na própria ordem natural das coisas e, portanto, o monarca jamais poderia prescindir de sua presença. Esse argumento favorável aos validos seria repetido várias vezes por outros defensores do valimento. Mas, Fray Pedro de Maldonado, que Antonio Feros considera o mais influente teórico do valimento no período da privança de Lerma ${ }^{29}$, definia da seguinte maneira a natural necessidade do privado tanto para o rei, quanto para o reino:

si el privado es bueno, le está bien al Rey y al reyno. Al Rey porque le dará mayor noticia de las cosas, encaminará mejor la razón, como quien tiene las llaves de su corazón, cuidará mejor de su vida, honra hacienda, y cociencia, como quien le paga amor con amor. Al reyno porque así se animarán otros a merecer la privanza, así se hacen los Reinos floridos y los grandes estados, y al fin tiene un midianero, que como del Reino haga sus partes y como más acepto al rey le alcance sus mercedes. ${ }^{30}$

Nesta mesma época, Don Francisco de Quevedo y Villegas (1580-1645), que anos depois dedicaria ao tema uma comédia, Cómo ha de ser el Privado ${ }^{31}$, em 1626, também procurou em várias de suas obras compreender o sentido do valimento e enquadrá-lo no âmbito do edifício monárquico. Tudo indica que entre os anos de 1606 e 1608, Quevedo deu termo ao seu pouco conhecido Discurso de las Privanzas, um Espelho de Privanza, cujo interesse inicial era definir de forma acabada qual era o real 
ofício do privado. A pergunta inicial que se colocava Quevedo no início do tratado é sobre qual seria efetivamente o ofício do privado. A priori, Quevedo identifica um paradoxo no fenômeno da privanza: "dificuldad tiene saber cuál, porque parece que todo y que nada: todo, porque es dueño de la voluntad del rey; nada, porque si han de dejar su auctoridad a los Consejos, jueces y ministros, no le queda a él cosa alguna". Mas o efetivo papel que o valido deveria desempenhar, segundo definido por Quevedo em seu Discurso, era ser uma espécie de meio termo entre o rei e o povo, isto é, um ponto de equilíbrio frente às tensões que abalariam o reino a qualquer momento. Neste sentido, caberia ao valido ser, ao mesmo tempo, o descanso para a vontade do príncipe diante do pesado fardo que era conduzir as coisas da república. Como dizia:

cosas que estrambas son de gran cuidado, porque si en la voluntad del rey está todo y en la suya del rey, menester ha vivir con prudencia y solicitud, mirando por su sosiego, recogimiento, templanza, entretenimiento honesto, encaminándole siempre a virtud y apartándole de todos los que le pueden apartar della. ${ }^{32}$

A rigor, o Discurso de Quevedo não apresentava diferenças substantivas de conteúdo frente aos demais Espelhos surgidos na época. Não obstante, a questão do valimento no interior do pensamento político de Quevedo é central, pois, em sua opinião e de todos aqueles que pensavam o problema, malfazejos conselhos dados por privados poderiam determinar a ruína da monarquia. Não nos alongaremos muito neste ponto, mas nos Grandes Anales de Quince Dias, crônica histórica do período de transição entre os reinados de Felipe III e Felipe IV, a questão do valimento aparece imersa em uma crítica severa à privança do Duque de Lerma ${ }^{33}$.

No entanto, foi na obra Política de Dios, gobierno de Cristo y tiranía de Satanás, escrita em torno de 1617 e impressa em 1635, dedicada a Olivares, que se vislumbram as mais profundas reflexões de Quevedo sobre o problema dos validos. Em sua visão, apesar das severas críticas que tinha aos defensores da 
Razão de Estado, mesmo que essa fosse a chamada boa ou verdadeira Razão de Estado cristã, defendida por pensadores como Giovanne Botero, Pedro Barbosa Homem, Diego Saavedra Fajardo, Pedro Fernandez de Navarrete e Baltazar Gracián, ${ }^{34}$ era perfeitamente plausível que o Rei tivesse algum afeto especial por algum amigo que o servisse na condição de privado. O que não admitia Quevedo era que o monarca viesse a se submeter às vontades do valido. Em síntese, cabe ao valido somente aconselhar e servir ao seu senhor, sem jamais tentar governá$10^{35}$.

Mas, retomando a análise dos Espelhos de Privanza, chegamos a outro interessantíssimo exemplo do modo como a questão valimento impactou o pensamento político: encontramos na obra do letrado Juan Pablo Mártir Rizo (1592/3? - 1642), que fazia parte do círculo de amizade de Quevedo e pugnava como este contra seus adversários. Entre os anos de 1625 e 1629, Rizo publicou a parte mais significativa de suas obras em que a questão do valimento é central em suas reflexões. Essas obras são o specula princips intitulado Norte de Príncipes (1626), as três biografias, Vidas de Sêneca, Mecenas e Biron, verdadeiros Espelhos de Privanza, além das traduções de obras do "historiador" francês Pierre Matthieu ${ }^{36}$. Esse período coincide com os primeiros anos do reinado de Felipe IV e o início do valimento de Olivares.

Em Norte de Príncipes, Rizo já defendia de forma clara que o Rei conte com o auxílio do valido, porque necessita de comunicação particular, porque os Príncipes necessitam de amigos para conduzir as duras tarefas de conduzir bem a grande máquina da monarquia. Não obstante, alerta que havia três qualidades que deveriam estar presentes no valido, o qual teria que ser rico, nobre e prudente ${ }^{37}$. Como ensinou Aristóteles na Política, todos aqueles que tivessem grandes funções e ocupassem grandes ofícios deveriam ser ricos. Deste modo, sendo o privado rico, não se deixaria levar por interesses financeiros, como afirmava Rizo: "no hay precio que mueva a hacer lo que es justo al que no necesita de cosa alguna"38. A nobreza seria uma qualidade cuja importância se baseava na 
certeza da herança que o indivíduo traz dos grandes, cujos exemplos de coragem, justiça e honra dos antepassados seriam os maiores espelhos para a vida dos privados. Daí, imitando suas ações, impor-se-ia um freio para práticas e pensamentos indignos, pois "mayor obligación tiene de ser virtuoso el noble que el que no lo fuera"39. Además: "viendo los otros grandes constituidos en tan próspera fortuna a persona igual con ellos en nobleza, le respetan, no le desprecian, lo cual no harían si el Príncipe le hubiese levantado a su grandeza de bajos principios, y así tiene la murmuración más modestia". ${ }^{40}$ Por fim, Rizo assinala que a prudência é a terceira qualidade inerente ao perfeito privado. Neste ponto, ele reproduz uma tópica muito importante no imaginário da aristocracia do Antigo Regime, em que ser prudente era sinônimo das mais altas virtudes e o ideal de sociabilidade mais importante para o perfeito cortesão. A virtude da prudência, somada à busca pela sabedoria e moderação do espírito eram na perspectiva estóica o caminho mais seguro para a vida reta e feliz ${ }^{41}$.

Mas, conforme indicamos anteriormente, foi ao longo das três Vidas que biografou que efetivamente o autor refletiu em profundidade sobre o problema da privança. Primeiramente, foi buscar na antiguidade clássica romana dois exemplos capitais. Fazendo largamente uso das obras de Tácito e Suetônio como fontes para sua narrativa, publicou em 1625, a Historia da vida de Lucio Anneo Séneca Español ${ }^{42}$ e, no ano seguinte, na Historia da vida de Mecenas ${ }^{43}$. A Vida de Sêneca imaginada por Rizo é bastante inovadora para a época. Lembremos que Sêneca e a filosofia estóica eram naquela altura extremamente influentes nos meios intelectuais europeus, em particular, no mundo Ibérico onde, inclusive, ocorreu a tentativa de afirmar que o filósofo fora verdadeiramente um cristão ${ }^{44}$. Não obstante, apesar de Rizo fazer referência a essas questões, não era exatamente o filósofo que lhe interessava, mas sim o político, conforme já observara José Antonio Maravall ${ }^{45}$. Em sua opinião, a mais importante lição a ser tomada do exemplo de Sêneca: um bom privado que serviu a um mau rei. Deste modo, era emblemático no sentido de ele representa o modelo do privado que atuava 
desprovido de segundos interesses, preocupado somente com a boa educação moral do Príncipe e zeloso em lhe apontar o melhor caminho a seguir. Conforme afirmava Rizo, repetindo de certa forma um pensamento recorrente no período ${ }^{46}$,

la educación es origen de todos los hábitos buenos y malos, es fundamento principal de toda la felicidad humana; de ésta se causa el establecimiento, la ruina de los Imperios, el mandar y servir de las naciones, el nacer ya caer de los Estados. Esta, si es bien ordenada, es madre de las buenas costumbres; éstas son las raíces de las buenas leyes, éstas el fundamento de las armas poderosas, y donde hay costumbres, leyes y armas en grado de excelencia, de necesidad conviene que sea grande el poder del Principado, gran felicidad de los súbditos, gran majestad la del Príncipe. La buena educación no es otra cosa que una buena y diligente cultura del ánimo, y donde se da lumbre al entendimiento, imperio de la razón, términos a la voluntad, freno de los afectos, regla a las acciones y gallardía al cuerpo. ${ }^{47}$

Inúmeros autores compartilharam dessa mesma opinião naquela época. Elemento chave no ideário humanista, tornou-se verdadeiro lugar comum entre os pensadores que se detinham em refletir sobre o universo da política a crença na capacidade de a "pedagogia" construir o bom governante. Em síntese, o ponto fundamental disso que tratamos é a percepção da forma como Rizo construiu a imagem de dois perfeitos Espelhos de Privanza tendo como base elementos extraídos da História Romana. Por outro lado, a Historia trágica de la vida del Duque de Birón $^{48}$ (1629) apresenta a imagem da vilania e torpeza em que seria possível descambar o valimento. Nessas três obras, Rizo elaborou uma sofisticada síntese sobre as possibilidades de privanza que a história contaria. $\mathrm{Na}$ verdade, imaginou que em torno desses três personagens poder-se-ia compreender os fundamentos da lógica do valimento e suas consequências para o governo da república. Sêneca representaria o modelo do bom privado, servindo a um rei perverso; Mecenas, o bom privado, com um mau rei e Birón, um mau privado, com um bom rei. 
Nessa mesma época, em outra obra que permaneceu manuscrita, mas provavelmente escrita no início da década de 30, intitulada Tardes de Alcázar. Doctrina Para el Perfecto Vassalo, de Juan de Robles (1574-1649), a questão aparecia de forma igualmente interessante ${ }^{49}$. Trata-se de uma obra na forma de diálogo entre duas personagens - D. Juan e o Licenciado que refletem sobre os aspectos básicos dos caminhos para se tornar um perfeito vassalo. Em certo sentido, o texto poderia ser definido como um Espelho de Privanza. As dedicatórias todas vão para Olivares, quem, na opinião de Robles, seria exemplo de perfeito privado. Na Tarde Segunda, o diálogo entre os dois personagens gira em torno de uma questão capital para o pensamento político do período: dever-se-ia ou não ter privados? Era Don Juan que colocava o problema: "quiero que V. M. me resuelva una questión; (....). Porque he advertido, que entre todos los que V. M. referió, no está el Privado. I deseo saber la causa dello; I si V. M. es de opinión que lo haya, o no". ${ }^{50}$

O Licenciado inicia sua argumentação justamente pelos juízos contrários à presença do valido junto ao rei, coisa que a maioria dos autores da época se inclinavam por concordar porque com a privança "se puede ensobervecer, i usar della prejudicialmente: I pretenden proba esto con los exemplos de Aman, $i$ otros dos o tres, que refieren las historias". Contrário a essa opinião, afirmava que "la sobervia, i el desvanecimiento, no está en los ofícios, o puestos; sino en las condiciones, i talentos, de los que los alcanzan". Neste sentido, havia privados que fizeram bom uso de sua privança " $i$ sean benignos, $i$ utiles á todos; $i$ havrá oficiales mui humildes de la casa real, tan desvanecidos, que no haya en la Corte quien se valga con ellos". Deste modo, sendo bom o valido, não há oficio mais importante ao rei e ao governo do que a privanza ${ }^{51}$.

Não obstante, o Licenciado prossegue em sua retórica favorável ao valimento e enumera mais duas razões básicas para que se tenha privado. A primeira razão, comum a outros defensores da privanza e aceita por alguns de seus críticos, era que "a todo hombre le es necesario, tener un amigo en especial; con quien comunicar interiormente sus negócios, i desabrochar su 
pecho, para alivio de sus cuidados, i diminuición de sus penas". Contra esse argumento, não haveria dúvidas e nem contradições possíveis. E sendo o fardo dos Reis demasiadamente pesado, pois era inerente à sua condição resolver todos os negócios da República, era mais do que necessário contarem com amigos fiéis com quem pudessem aliviar o peso de seu cargo ${ }^{52}$. Já a segunda razão, intrinsecamente relacionada ao escopo de toda argumentação realizada por Robles através da fala do Licenciado, merece ser lida na íntegra:

Que, siendo estilo ordinário de sus Magestades el elegir todos sus ministros por consultas, i informes de las personas, á quien tiene cometido esto, sin usar de su voluntad, sino solo por su confiança, i credito de quien le informa. Será justo, i piadoso, i no menos necessário; eligir un ministro especial siquiera, que pueda llamar suyo proprio, electo de su propria voluntad; i afición; A quien haya conocido de atras por trato, i comunicación: Como se suelen conocer comumente las demás personas: Porque le havemos de obligar, á ser Rei perpetuamente, que no se le conceda acción ninguna de hombre. Que esta será fortíssima prohibición. ${ }^{53}$

Em outro plano argumentativo, Robles insere a privanza na própria natureza mística do corpo da monarquia. Em seu entendimento, o valido seria como a garganta: "que bien vee V.M. que ni se menea; ni sustenta; ni aprieta como las manos; ni anda como los pies; Ni haze otra operación visible". Todavía, apesar desse papel aparentemente invisivel e secundário, é ela quem dá "passo a la respiración, i al manjar, $i$ a las influencias de la cabeça, i a los Vapores del estómago: administra la más importante de nuestro compuesto para la conservación de su ser". A garganta, insiste Robles, além de ser uma espécie de instrumento para que a cabeça possa movimentar-se para os lados, a sustenta sobre os ombros ${ }^{54}$. Neste sentido, não haveria mais dúvidas, e insiste o Licenciado:

Pues persuadase V.M. que esso, o semejante a esso viene a ser el privado en este cuerpo místico; Cuya cabeza es el Rey; I todos los 
demás grandes, i pequeños, el Cuerpo compuesto dellos como de miembros: Los cuales todos están (cada uno a su modo), pendientes de aquella cabeza; atendiendo a ella, i a sus influencias. I assi, el docto quiere remontarse; I el discreto acreditarse; I el interesado aprevecharse; I el corto no se atreve; I el astuto inventa, o finge. I todo esto va a para un Monarca, que de su prefession no es letrado; $\mathrm{Ni}$, por su grandeza, puede, tener noticia de las cosas ordinarias, i caseras; $\mathrm{Ni}$, finalmente, por humano, puede conocer a todos, ni saber los intentos de todos. I juntamente tiene (por quienes) menor imperfeción del Mundo; sino antes tan estremada perfeción, que todos vayan satisfechos, i acreditados, i admirados, i gustosos de tener tal Rey, i señor. Vea pues V.M. como se puede con esto administrar todo esta maquina, si no ay una garganta, que sirva esta cabeza; Y le ayude (digasmolo assi) advertiéndole de coger de tal suerte, que no se suceda desaire ninguno, no cosa indigna de la Magestad Real. I que obre después de esso perpetuamente en todo obras verdaderamente dignas Della. ${ }^{55}$

Diante dessas evidências, conclui então Robles que não somente era lícito ter privados, mas seria impossível pensar os reis e monarquias sem eles. Como se pode observar, neste período, marcado pelo pleno valimento do Duque de Olivares, considerado por Robles espelho de todos os Privados, cresce significativamente o número de obras com elogios e defesa do valimento.

Além dos espelhos já analisados aqui, vale mencionar alguns mais. José Pellicer de Ossau y Tovar (1602-1679), nobre, Cavaleiro da Ordem de San Thiago, Conselheiro do Rei, cronista oficial de Espanha, destacado intelectual relacionado ao círculo de Olivares e um dos letrados conclamados por ele para defender através da pena o regime, em 1639 publicou um pequeno espelho intitulado La Constancia christiana, necessária a um valido ${ }^{56}$, com forte influência tacistista e estóica pela via de Justus Lipsius (1547-1607), pois a virtude da constância, não pensada nem por Aristóteles nem por Cícero, mas imaginada por Sêneca, na visão de Lipsius era de capital importância para a vida civil. Na obra De Constantia ${ }^{57}$, publicada em 1584, a idéia 
principal gira em torno do fato de que é necessário mudar seu pensamento para evitar os males públicos, não mudar o lugar. A constância pode ser definida nestes termos: uma força de pensamento determinada, inabalável, que cultiva a paciência mesmo quando são graves eventos externos. Na visão de Lipsius, deve-se compreender que a virtude da constância exige que se faça uma distinção entre opinião e razão, sendo a primeira um foco de inconstância. Portanto, cultivar a razão leva à constância, que por sua vez liberta o homem de emoções como a dor, o desejo, a euforia e o medo. Neste sentido, o livro de Pellicer y Tovar remete o ideal da perfeita privanza ao exercício da virtude da constância, isto é, à pratica da razão, ao exercício da paciência e à luta permanente por superar os exageros dos sentidos. Através da constância e da prudência, procurava-se atingir o justo meio e o controle absoluto das emoções.

Pela mesma altura, em 1641, Fray Jose Laynez publicava a obra de defesa do valimento, El Privado Christiano, deducido de las vidas de Joseph y Daniel, que furem balanzas de los Validos en el fiel contraste del pueblo de Dios, na qual sustenta através de argumentos fundamentalmente de ordem religiosa a legitimidade do valimento. Contrário àqueles que criticavam o valimento por inexoravelmente conduzir o reino a disputas, tiranias e crises desestabilizadoras, Laynez afirmava que "siempre fue contrario mi sentir, y juzgo que si el Privado es como debe ser, es la más noble y rica prenda de la Corona del Rey"58. Em vários momentos de sua obra, Laynez chama os validos de "ministro soberano", denotando o significado de sua legitimidade no âmbito da constituição política da monarquia. Mas, a certa altura, ele lança mão de um argumento ousado para a época e associa o valimento à própria vontade divina. Diz: "Dios elige Privado como Rey; da los Impérios y las bases em que se afirman" 59 .

Jerônimo Ortega y Robles, quase no final da década seguinte, em El despertador que avisa a un Príncipe católico, ya de las inquietudes de la guerra y ya de los sosiegos de la paz. Hecho de la vida del Emperador Constante, emitia semelhante opinião acerca do caráter divino da privança: "los privados son 
permitidos por Dios, que fue quien primero hizo elección de ellos"60. Entretanto, além desse argumento de ordem transcendental, defende, à maneira de muitos outros propagandistas do valimento, que "el Príncipe deba tener uno que le ayude en las resoluciones" $"$.

Entretanto, é interessante observarmos as relações entre o gênero específico dos Espelhos de Privanza e outras obras mais gerais da literatura política ibérica do período, que também buscaram explicar os fundamentos constitutivos e a legitimidade do valimento. Ainda no contexto da hegemonia de Olivares, temos na obra do Fray Pedro Martinez de Herrera, El Príncipe ardvertido y declaración de epigramas de Nápoles la vispera de San Juan, obra impressa em 1631, em que surgia novamente o argumento fundamental em todos os Espelhos de Privanza de que o Rei precisa de amigos para conduzir os pesados negócios da monarquia e por isso era necessário que existissem os privados:

$\mathrm{Ni}$ es vicio del Príncipe ni ambición del Privado tener esta familiaridad. Es necesidad en el Príncipe y en el vassalo suplemento. El Rey, porque no lo puede todo, se fía de un amigo en el gobierno, y el vassalo suple con su amistad lo que a las fuerzas del Príncipe les falta. ${ }^{62}$

Vicent Mut, em El Príncipe en la Guerra y en la paz, em linhas gerais, prosseguia no tópico de que o Príncipe não deveria governar solitariamente, porque "es pesada la máquina del Imperio", sendo difícil deliberar sem compania, e afirma: "he menester amigos, porque no hay posesión agradable sin un amigo". Todavia, Mut fez questão de estabelecer o seguinte balizamento entre os conceitos de privado e de amigo:

Los que llama el vulgo privados, llamo yo amigos, porque conviene que aquéllos sean amigos, y más puede fiar y assegurarse el Príncipe de un amigo, que del privare sólo por el mérito: por el merecedor, obra para el beneficio comun, y el amigo para el Príncipe. ${ }^{63}$ 
Em tese, portanto, para Mut, o modelo do perfeito privado traduzia-se na verdadeira amizade entre o Príncipe e alguém especial que desfrutava de sua intimidade e confiança. Este tipo de relação estava acima de qualquer relação baseada no mérito que algum súdito pudesse conseguir. Deste modo, escreve mais à frente que, "quieren algunos que el Príncipe no ha de tener un solo privado...Yo, siguiendo a Justiniano, pienso que acierta el

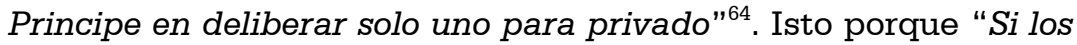
que son privados son los amigos, uno solo ha de ser el privado, porque uno solo ha de ser el amigo verdadero". ${ }^{65}$ Praticamente repetindo as razões apontadas por Mut para o processo de estabelecimento do valimento a partir do primado do melhor amigo, Ortega y Robles, em obra já citada anteriormente, dizia que "no hay, pues, causa que pueda impedir al Príncipe tener privado. El Principe desea natualmente como los demás, y elige como todos a aquel a quien se inclina el genio o el natural". Ou seja, era um direito natural concedido a todos pelo Criador escolher e possuir um melhor amigo. Porque, em sua opinião como na dos demais autores que se valiam dessa argumentação -, era melhor procurar conselhos em somente um amigo fiel que em vários pretensos amigos ${ }^{66}$. Neste mesmo ínterim, Fray Salvador Mallea, da ordem da Santíssima Trindade, na obra Rey pacífico y gobierno de Príncipe católico (sobre el salmo 100 de David), dizia que a todo homem é, por natureza, senhor de escolher um melhor amigo, e isso sucede também com os Príncipes ${ }^{67}$. Assim, é impossível desconsiderar a necessidade do privado como a personificação da idéia de melhor amigo, o que, por sua vez, simboliza de maneira clara o ideal de perfeito privado.

Neste ponto, retomemos o diálogo do início deste artigo com Diego Saavedra Fajardo. Tal como outros representantes do pensamento político espanhol do século do ouro, Fajardo sustenta que há uma inclinação natural entre os homens à constituição de laços de amizade - fundamentos da própria vida social, segundo a visão de mundo da época. Portanto, ao Príncipe não seria justo negar-lhe tal direito natural, isto é, ter amigos e conceder-lhes a graça do valimento. Conforme diz, até 
Felipe II, conhecido como Rei prudente, teve não um, mas vários privados ${ }^{68}$. Repetindo uma opinião comum na época entre os apologistas do valimento, os privados seriam aqueles que ajudariam os Príncipes a vencer as dificuldades. Ou seja: "el peso de Reinar es grave, i pesado a los ombros de uno solo". ${ }^{69}$ Mais à frente, reiterará esse aspecto que faz parte dos argumentos centrais de suas ideias sobre o valimento: "No ai Príncipe tan prudente, i tan sábio, que con su sciencia lo pueda alcanzar todoo, ni tan solicito, i trabajador, que todo lo pueda obrar por si solo". ${ }^{70}$ Até aqui, a exemplo dos demais autores que estamos analisando, Fajardo fundamenta o modo-de-ser criador e a necessidade do valimento na própria lei natural, na predisposição que o homem tem a possuir um melhor amigo com quem possa contar nas horas difíceis.

Em trabalho anterior ${ }^{71}$, havíamos discutido as complexas imbricações entre os significados simbólicos da ideia de amizade e de valimento no Antigo Regime. Sustentamos que, em torno da linguagem dos afetos, erguiam-se os elementos constitutivos das próprias práticas sociais oriundas de tessituras mais profundas da vida comunitária. Eram os signos em torno dos quais se estruturavam os elos de sustentação que permitiam à constituição da própria identidade humana a que os indivíduos estavam sujeitos. Ter amigos e, da mesma forma, viver de forma amorosa com o semelhante, representava a própria divisão natural entre a civilização e a barbárie. Diferentemente de hoje em dia, quando os significados do amor e da amizade são colocados na dimensão restrita da esfera privada, naquela época, havia forte conexão entre esses signos e a própria forma através da qual a sociedade se estruturava em suas mais diversas dimensões. Se olharmos para os discursos sobre a política, a sociedade, a economia ou a justiça, perceberemos que a semântica dos afetos integrava a forma como as coisas assumiam sentido.

Contudo, essa compreensão, por assim dizer, ampla da amizade e do amor como elementos constitutivos das sociedades do Antigo Regime, no que se refere à ideia de amizade como tradução do primado essencial de justificação do 
valimento, que era o natural direito de o Príncipe escolher um melhor amigo, segundo pensada pelos autores que estamos analisando, causava sérias controvérsias. Isto porque a consolidação do privado no centro do poder, ocupando o coração do afeto e da graça régia, significava, até certo modo, a ruptura com a compreensão da ordem social ideal e a perspectiva de governo vigente até então na Monarquia Católica. $O$ descolamento para o centro da afetividade régia que o privado vivenciava, assumindo a preferência do amor régio, inevitavelmente, como dissemos, causaria um forte movimento de críticas e resistências. Identificado com o individualismo e outras ordens de sortilégios relacionadas aos ensinamentos dos chamados "políticos" e "estadistas", a privanza, na verdade, suscitaria uma profunda reflexão sobre as novas demandas do poder. Esse fenômeno significou um fator imperativo novo na ordem política e fez com que sofisticadas elucubrações surgissem para dar conta da novidade. A afirmação do valido junto ao trono representou, portanto, uma ruptura na própria forma de compreender a monarquia, inegavelmente, através da aproximação que os autores Ibéricos tiveram com o chamado novo humanismo representado pela difusão das obras e ideias tacitistas e da doutrina da Razão de Estado nas últimas três décadas do século XVI. Na Península Ibérica, apesar dos pressupostos do velho humanismo, cujas autoridades de Aristóteles, Cícero e Santo Tomás eram inquestionáveis e se constituíam em verdadeiro paradigma no quadro da Contra Reforma, começavam a se expandir teses que se vinculavam com o novo humanismo, em que tacitismo, estoicismo e a doutrina da Razão de Estado distanciaram-se do paradigma aristotélico-ciceroniano-tomista ${ }^{72}$.

Mas, retomando a análise do diálogo com Fajardo, ao observar as autoridades às quais recorre para fundamentar seus argumentos, percebemos claramente essa lógica. Especificamente nessa Empresa, encontramos referencias à Bíblia, Tácito, Cassiodoro, Petrarca e Juan de Mariana, o que evidencia o pressuposto de Fajardo em construir a imagem tanto da boa quanto da má privanza, através dos ensinamentos dos 
antigos e dos modernos. Enfim, partindo do princípio ciceroniano de que a história era mestra da vida, comum entre os autores que pensavam a política no período, tomar exemplos tanto da história sagrada quanto da profana para expor de forma clara e verdadeira suas idéias, tal como praticamente todos os autores que analisamos aqui, Fajardo recorria às Sagradas Escrituras para retirar inúmeros exemplos de como o próprio Deus intervinha criando situações em que o valido tornava-se personagem importante à sua obra. $O$ Criador, ainda que escolhesse a Moisés para guiar o seu povo, mandou que este "valiese de los mas viejos", principalmente seu sogro Sethro, para que lhe ajudassem a fazer o duro trabalho de conduzir o povo de Deus à terra prometida ${ }^{73}$. Exemplos da boa privanza, Fajardo indica Daniel, que serviu a Dario, Joab, que serviu David, Jose, fiel servidor do faraó. Como negativos exemplos da privanza, Fajardo cita Sejano, privado do Imperador Tibério e Don Álvaro de Luna, valido de Don Juan II, de Castela do século $\mathrm{XV}$, personagens que se configuraram em verdadeiros emblemas da maldade, principalmente na memória social Ibérica ${ }^{74}$. À pergunta, recorrente entre os autores da época, se o Rei deveria ter um ou mais ministros e conselheiros, isto é, um ou mais privados, Fajardo responde claramente que o mais conveniente seria ter um valido, por si fossem muitos e igualmente favorecidos e poderosos os favoritos, haveria o perigo constante das competições e lutas entre eles, um grande perigo para o governo da República. Desta maneira, conforme "pareze el orden natural, que se reduzgan los negocios à un ministro solo, que vele sobre los demás, por quien pasen al Príncipe digeridas las materias, i en quien este substituido el cuidado, no el poder, las consultas, no las mercedes"75. Novamente, a metáfora do sol e da lua serve de justificativa para essa tese.

Un sol dà luz al mundo, i quando tramonta deja por presidente de la noche no à muchos, sino solamente à la luna, i con mayor grandeza de resplendores, que los demás astros, los quales como Ministros inferiores le asisten: pero ni en ella, ni en ellos es propia, sino prestada la luz, la qual reconoce la tierra del Sol. ${ }^{76}$ 
Neste sentido, o segredo do bom valimento deveria ser, em primeiro lugar, eleger o valido entre os Grandes do reino, apesar de que Fajardo não ver inconveniente em premiar o mérito. Porém, a essência do bom valimento advinha da prudência mútua que tanto o Príncipe quanto o valido deveriam possuir e guardar, porque "todo el punto del valimiento consiste, en que el Príncipe sepa medir quanto deve favorezer al Valido, i el Valido quanto deve, desejarse favorezer del Principe. Lo que excede desta medida, causa (como diremos) zelos, invidias, i peligros"77.

Pouco tempo depois, o famoso jurista espanhol Juan de Solorzano Pereira (1575-1655), em sua obra de emblemática, Emblemata Regio-Politica ${ }^{78}$, concebera um total de cem emblemas que constituiu um dos mais importantes specula princips do século XVII. Dentre eles, existe o emblema cujo mote é Administri Principum ${ }^{79}$, que, apesar de não se posicionar favoravelmente à existência do valimento ${ }^{80}$, versa exatamente sobre a importância de o Príncipe contar com bons ministros e conselheiros para auxiliar-lhe nos negócios de governo, retomando questão já presente nos autores que analisamos até aqui, principalmente em Fajardo, acerca da necessidade natural de os Príncipes terem validos.

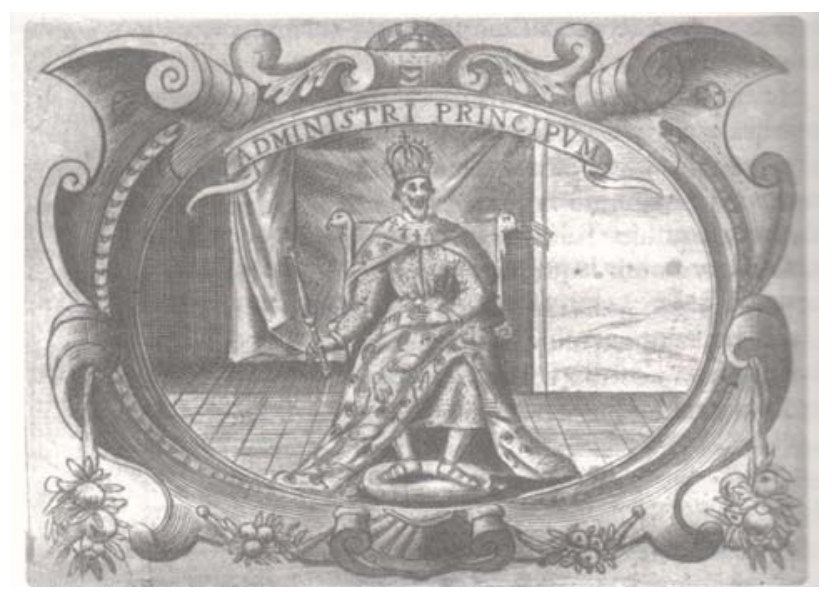


A gravura que ilustra o emblema apresenta a pessoa régia, com coroa e cetro real, disposta em destaque no centro da figura. Seu manto encontra-se repleto de bordados que representam olhos, orelhas e mãos. Essa, na visão de Solòrzano, seria a imagem do bom conselheiro ou ministro do rei. Não obstante, é interessante observamos que pouco tempo depois, por intermédio do Padre Jesuíta Andrés Mendo (1608-1684), Calificador del Consejo de la Inquisicion Suprema, Lector de Theologia y de Sagrada Escritura em Salamanca, em Príncipe Perfecto y Ministros Aiustados. Documentos Políticos y Morales em Emblemas, impresso pela primeira vez em $1662^{81}$, "apropriarse-ia" de cerca de 80 emblemas originalmente concebidos por Solorzano Pereira, daria uma nova interpretação ao citado emblema Administri Principum ${ }^{82}$, em que faz explícita defesa do valimento. Tal como Solòrzano, através dessa representação, Mendo buscava sugerir que o Príncipe deve rodear-se de ministros e conselheiros que lhe ajude em seu árduo labor de governo, pois na maioria das vezes, uma só pessoa não basta para guiar no rumo correto a nave da monarquia. Assim, era necessária a ajuda de ministros prudentes e zelosos como pilotos, marinheiros e grumetes da dita nave. O Príncipe necessita, portanto, de ministros responsáveis que fossem seus olhos, mãos e ouvidos para lograr atender a tudo o que concerne ao Reino. Governar todo um Império era uma carga demasiadamente pesada para que somente um homem o fizesse, por isso era necessário que o Príncipe se apoiasse em bons Conselheiros, porque o Príncipe há de ouvir a muitos, há de ver tudo que se passa em seu Reino, e mais: "ha de disponer innumerables negócios de paz y guerra en Províncias cercanas, y distantes". E não basta somente um entendimento, ou, como diz, "ni unas potencias, y sentidos solos à comprehenderlo". Era preciso, pois, "valerse de fieles Ministros" ${ }^{83}$. Ainda mais enfático, afirmava:

Nuestra vida en todas las ocupaciones necesita de ayuda. Y para el gobierno sirven de ojos, manos, y alivio los Ministros. No rige una nave un hombre solo; necessarios son pilotos, marineros, y 
grumetes; No fabrica una casa solo el architecto, sin que le ayuden oficiales, y peones; Y mucho menos se puede regir la nave de una Republica, y de un Reyno, ni fabricar en el, el edificio del gobierno político, sino ay muchos, que ayuden, y cooperen. ${ }^{84}$

Neste ponto, Mendo afasta-se da visão original de Solòrzano Pereira. Tal como quase a totalidade dos autores que estamos analisando, Mendo desenvolveu um dos argumentos chave nos discursos que procuraram legitimar o valimento. Ou seja, em virtude da necessidade básica de se procurar permanentemente alcançar a boa governança do Reino, surge quase que naturalmente a legitimidade de se ter valido. Mendo defende que o Príncipe tenha um supremo ministro e que esse seja um valido. Este, além de servir como instrumento de alargamento dos horizontes régios, serviria também como alguém que, na qualidade de melhor amigo, traria alívio diante das agruras do poder, seria quem lhe comunicaria "lo más oculto; encomendar lo secreto; que en los sucesos prósperos le dè sinceros parabienes; se compadezca en los adversos, y le aliente en sus fatigas" ${ }^{85}$.

Enfim, na segunda metade do século XVII, apesar do eclipse de valimentos como os de Lerma e de Olivares, permanecia ainda viva a defesa da necessidade de se ter privados junto à realeza hispânica. A literatura política da época permanecia atenta à questão e produziam-se importantes Espelhos de Privanza. Bom exemplo disso é a obra Logros de la Monarquia en aciertos de un valido, de Pedro de Navarra y De la Cueva, Cavallero de la Orden de Santiago, Marques de Cabrèga, Mayordomo de la Reina Nuestra Señora, publicada em 1669, cujo título já sugere o teor da defesa que faz do valimento. Em termos gerais, podemos dizer que a obra de De la Cueva é pouco original e segue os argumentos já apresentados aqui, em que a privanza fundava-se no amor e na perfeita amizade entre duas pessoas, algo que naturalmente aconteceria entre iguais, pois cada um deveria ter um amigo especial, um privado fiel em que se fiar nos momentos mais difíceis e tortuosos. A primeira ordem de argumentos a favor do valimento baseia-se em textos das 
sagradas escrituras, fenômeno mais do que recorrente nos textos que analisamos anteriormente. Segundo dizia, o próprio Espírito Santo e outras autoridades bíblicas já haviam advertido que "Sean tus amigos muchos, y el Consejero uno. Y Santos, y sabios todos dan por consejo, que para descanso de los trabajos, para la luz en las dudas, para noticia de las faltas proprias, cada uno tenga su Privado fiel, y verdadero". O problema, dizia ele, era "si los Reyes, y personas publicas le podrân tener" ${ }^{86}$, visto para muitos autores o valimento, como dissemos atrás, era causa de conflitos, disputas e toda ordem de sortilégios que se acometiam à República, cujo exemplo privilegiado, como era quase regra citar, foi Don Álvaro de Luna, valido do Rei de Castela, Don Juan II. Para responder a essa pergunta que atormentava quem se debruçava sobre as questões da política e contornar os problemas que a história mestra da vida ensinava, De la Cueva, repetindo claramente Fray Pedro de Maldonado, afirmava:

si el Privado es como debe ser, es la mas noble, y rica parte del Rey, por tres razones: la primera, fundada en el ejemplo de quantas cosas ay superiores. El Sol (aunque â todo lo inferior haze bien) ciertas partes de la tierra, con sus mejores diposiciones, son dêl mas favorecidas, criando en ellas las minas de oro, y plata. El Alma (aunque â todo el cuerpo vivifica, y da vigor) pero â la cabeça, y coraçon comunica mas particulares favores. El mismo Dios (en quanto superior natural â todas las criaturas dâser) pero no a todas hizo igualmente cercanas y parecidas a si. Y ( aunque superior sobrenatural, a todos da su gracia) pero a unos mas que a otros. ${ }^{87}$

Desse modo, inscrito na própria ordem natural das coisas, e sendo a privança revestida de uma áurea de bondade, o reino e o rei seriam os maiores beneficiários - "si el Privado es bueno, le esta bien el Rey, y al Reino", dizia. O privado daria ao rei a "mayor noticia de las cosa, encaminará mejor la razon, con quien tiene la Haves de su coraçon, cuidarâ mejor de su vida, honra, hazienda, y conciencia, como quien le paga amor con amor". 
Assim, não seria justo negar ao rei, um coração tão aflito em virtude do peso que era guiar a grande nave da monarquia, dividir com o melhor amigo esse fardo, pois como dizia, "el amigo fiel es escudo fuerte, pictima vital, el que le hallo, hallo un tesoro". Igualmente, o Reino, porque "assi se animan otros â merecer la Privanza, assi se hazen los Reinos Floridos, y de grandes Estados. Y al fin tiene un medianero que (como del Reino) haga sus partes, (como mas acepto de Rey) le alcance sus mercedes". Nesse sentido, conclui: "nunca al Pueblo de Dios le fue bien, sino quando su Principe tenia un buen Privado: Faraón a Joseph, A fuero un Mardoqueo, Baltasar un Daniel, y Saul un Samuel..."88.

Diante de todos esses argumentos e justificativas favoráveis ao valimento, imaginando-o enquanto elemento naturalmente intrínseco à organização da própria monarquia, cabe-nos resumir o conjunto de virtudes que os validos deveriam possuir para que fosse positivo o exercício da privanza. $\mathrm{Na}$ década de 1670, as obras de Juan Baños de Valasco (?-1682) retomam a questão da defesa da privanza e concebe a imagem do perfeito privado, fundamentada na figura de Sêneca e na filosofia estóica, tal como já havia feito Juan Pablo Martin Rizo. As obras Lanneo Seneca ilostrado en blasones politicos j morales ${ }^{89}$ e El sabio en la pobreza, commentarios estoycos, j historicos a Seneca ${ }^{90}$ publicadas, respectivamente, em 1670 e 1671, principalmente El ayo y maestro de principes Seneca en su vida ${ }^{91}$, de 1674 , são a realização do projeto intelectual de construir a imagem do perfeito privado tomando como modelo o filósofo estóico. Não obstante, na década seguinte, Gaspar Augustin Lara, no espelho Equilíbrio Christiano político y moral que pondera, proporciona y mide los passos Del primer Ministro por el árduo camino de la Privança para sentarlos firmes y conducirlos seguros al encubrado logro de la Monarquia del Mayor Monarcha de dos Mundos D. Carlos Segundo de Nustria em los aciertos de su digníssimo valido ${ }^{92}$, retomaria várias dessas questões no sentido de apontar as virtudes inerentes à perfeita privanza. Mas, de forma abrangente, praticamente todos os autores concordavam que o valido deveria ser, acima de tudo, 
prudente. Além disso, ao valido seria importante praticar caridade, demonstrar humildade e sabedoria, como resumiu Fray Enrique de Mendonza ${ }^{93}$. Já Fray Pedro de Maldonado, citado anteriormente, dizia que as virtudes do valido poderiam se reduzir a quatro: amar sem idolatria, ensinar sem presunção, lisonjear sem adular e praticar a humildade ${ }^{94}$. Comportando-se assim, o valido deveria ser ao fim e ao cabo amável, respeitador e magnânimo. Mateo Renzi, outro a escrever um Espelho de Privanza, por sua vez, aconselhava a Olivares que fosse modesto, zeloso de sua reputação, prudente e verdadeiro ${ }^{95}$. Não obstante, conforme lembra Tomás y Valiente, quase todos os autores que trataram da privanza diziam que ao valido era fundamental ser trabalhador e incansável servidor do Príncipe ${ }^{96}$.

Como último exemplo sobre como se imaginou o perfeito privado, observemos a carta escrita supostamente a Estanislao Borbio, valido do Rei da Polônia, por Pedro Fernandez Navarrete, em 1612. Este texto proporcionaria à literatura política do período uma interessante síntese do debate coevo sobre a questão do valimento, configurando-se em verdadeiro Espelho de Privanza. De orientação tacitista, Navarrete advertia que as virtudes do perfeito privado situavam-se em duas ordens: uma externa e outra interna. Por essa última compreendia os meios através dos quais se constituiria todo bom cristão, isto é, um sujeito temente a Deus e seguidor de suas leis. Todavia, segundo pensava, somente isso não bastaria para a perfeita privanza. Eram necessárias as virtudes exteriores concernentes à vida política, que deveriam ensinar a cuidar do bem comum. Nesse sentido, o valido deveria ser prudente, moderar suas ambições e demonstrar permanentemente humildade, praticar a modéstia sincera, demonstrar permanentemente amor, lealdade e fidelidade a seu Príncipe. Além disso, havia que se praticar diariamente a virtude da constância que, como vimos, apregoava Justus Lipsius e os neo-estóicos. Mas, o valido também deveria saber praticar a arte de ser discreto, mesmo que para isso fosse preciso dissimular e usar de outros artifícios que lhe associassem à Razão de Estado maquiavélica ${ }^{97}$. 
A ideia de perfeito privado, assentada em um vasto quadro de polêmicas em torno da nova arte de governar ${ }^{98}$, foi uma resposta decisiva da literatura política espanhola do Antigo Regime a essa realidade da monarquia. Enfim, ao longo de todo esse período, buscou-se imaginar o melhor modelo de conduta que o valido deveria encarnar, pois, afinal, de suas virtudes, dependeria o destino da própria monarquia. Neste sentido, a história dos validos, privados e favoritos régios do Antigo regime é um capítulo chave na construção do espaço institucional da figura do Primeiro Ministro. Mas essa seria uma conquista futura, pois, apesar da insistência de muitos dos mais poderosos privados que conhecemos em construírem a sua auto-imagem associada à idéia e ao simbolismo que o conceito de ministro representava, por mais institucionalizada que fosse a situação de algum privado, como ocorreu com o Duque de Lerma e mesmo com Olivares, a sua trajetória no espaço áulico, verdadeiro teatro da fortuna, era regida acima de tudo pela necessidade de ser amado pelo Rei. Nenhum dos personagens referidos aqui pode prescindir da condição sine qua non do valimento: ocupar o centro da afetividade do monarca, ser seu melhor amigo. Talvez, fosse essa a sua principal virtude.

OLIVEIRA, Ricardo de. The Best Friend of the King: The image of the perfect privanza (favorite) in the Hispanic Monarchy of the $17^{\text {th }}$ Century. História, v.28, n.1, p.653-696, 2009.

\begin{abstract}
The controversial character of the influential or favorite was reason for innumerable disputes during the $17^{\text {th }}$ century within the sphere of the Hispanic Monarchy, mainly in the context of the reigns of Philip III and Philip IV. A number of authors had come to attack the figure of the favorite with regards to this theme, but many others had defended its legitimacy as the king's devoted friends assisted in the conduction of the Empire's business. Intrinsic to this phenomenon is the creation of the literary genre called Mirror of the Favorite. This article intends to question the meaning of some of these positive
\end{abstract}


manifestations of influence in the sphere of $17^{\text {th }}$ century Spanish political thought.

Keywords: Influence; Hispanic Monarchy; Political Thought.

\section{NOTAS}

${ }^{1}$ Este artigo apresenta alguns resultados do Projeto de Pesquisa À Sombra do Rei. Valimento e Favoritismo Régio no Pensamento Político Ibérico do Antigo Regime - Séculos XVI e XVII, financiado pela FAPERJ, através do EDITAL / MCT/ CNPq/CT-INFRA - No 03/2006 Programa Primeiros Projetos.

${ }^{2}$ A fortuna editorial dessa obra foi realmente extraordinária. A edição princips é a de Mônaco, impressa em 1640. Mas, até onde foram nossas investigações, somente durante o século XVII, contabilizamos um total de 10 edições latinas, 12 castelhanas, além de traduções para o alemão (1655), o holandês (1662), o francês (1668) e o inglês (1700), com respectivas edições. Não há referência de autoria das gravuras. $O$ emblema que ilustra o início deste artigo foi retirado da referida edição de 1640. Ver: FAJARDO, Don Diego de Saavedra. Idea de un Principe Político Christiano, Representada en Cien Empresas. Monaco: Nicolao Enrico, 1640. fol. 511. Na edição de Milão, de 1642, do mesmo impressor, a Empresa em questão está disposta de forma diversa e apresenta pequenas modificações na gravura. Ver: FAJARDO, Don Diego de Saavedra. Idea de un Principe Político Christiano, Representada en Cien Empresas. Monaco: Nicolao Enrico, 1642. fol. 335 e segs. Também consultamos a edição moderna das Obras de Don Diego Saavedra Fajardo. Madrid: Real Academia Española / Atlas, 1947. p. 125.

${ }^{3}$ Admite-se que a literatura de emblemas foi criada no início do século XVI pelo humanista italiano Andrea Alciato (1492-1550), cuja obra Emblematum Líber, impressa pela primeira vez em 1531, conheceu notável fortuna editorial e gozou de expressiva popularidade durante os séculos XVI e XVII, exercendo grande influência nos meios intelectuais. Trata-se de uma coleção de 212 emblemas com poemas escritos em latim. Em cada emblema existe um mote - provérbio ou expressão enigmática curta -, um retrato e um texto epigramático. $\mathrm{O}$ livro de Alciato teve mais de 21 edições durante o século XVI. Todavia, 
de forma bastante genérica, os autores ibéricos do Antigo Regime usavam os conceitos de empresa e emblema como formas sinonímicas. Por exemplo, em 1611, Sebastián de Covarrubias, no Tesoro de la Lengua Castellana o Española, definia emblema como algo que, metaforicamente, se denominam "los versos que se subscrivem a alguna pintura o talla, con que sinificamos algún conceto bélico, moral, amoroso, o en outra manera, aydando a declarar el intento del emblema y de su autor. Este nombre se suele confundir con el de símbolo, hieroglífico, pegma, empresa, insigna, enigma, etc." Já empresa, definia Covarrubias, "es cierto símbolo o figura enigmática hecha con particular fin, endereçada a conseguir lo que se va a pretender y conquistar o mostrar su valor y ánimo". Mais de cem anos depois, os significados atribuídos aos dois conceitos permaneciam praticamente inalterados na língua Castelhana. O Diccionario de la Lengua Castellana, também conhecido como Diccionario de Autoridades, na primeira edição de 1732, define empresa (empressa) como "Cierto symbolo ò figura enigmatica, con mote breve y conciso, enderezado à manifestar lo que el ánimo quiere ò pretende...". O mesmo Diccionario registra que se entendia por emblema, em castelhano, "cierto géreno de Jeroglífico, y símbolo o empresa, en que se representa alguna figúra ò cuerpo de cualquier género ò especie que sea, al pié de la cuál se escriben unos versos, en que se declara el concepto ò intento que se encierra en ella: y casi siempre es de cosas morales y graves." Ver: COVARRUBIAS, Sebastián de. Tesoro de la Lengua Castellana o Española." (1a. Ed. 1611) Barcelona: Alta Fulla, 1998. pp. 506 e 509. (Ed. Facsimilar); REAL ACADEMIA ESPAÑOLA. Diccionario de La Lengua Castellana. Madrid: Imprenta de la Real Academia Española, Tomo Tercero, 1732. pp. 389 e 417. Todavia, Juan de Covarrubias Horozco, irmão de Sebastián de Covarrubias, em seus Emblemas Morales, publicados em 1604, ao longo do Livro Primeiro, na verdade um grande tratado teórico sobre a questão dos emblemas, propõe uma diferenciação entre esses conceitos. Ver: COVARRUBIAS HOROZCO, Juan de. Emblemas Morales. Zaragosa: Juan de Bonilla \& Alonso Rodríguez, 1604. p. 9 e seguintes. Sobre a problemática da literatura de emblemas, ver: PRAZ, Mario. Imagenes del Barroco. Estudios de Emblemática. (1 ${ }^{\mathrm{a}}$. Ed. 1934) Madrid: Edicciones Siruela, 2005. MARAVALL, José Antonio. Teoria Española del Estado en el siglo XVII. (1 ${ }^{a}$. Ed. 1944) Madrid: Centro de Estudios Constitucionales, 1995.___. "La Literatura de Emblemas como técnica de accion socio-cultural en el Barroco". In: Estudios de Historia del Pensamiento 
Español. Madrid: Centro de Estudios Constitucionales, 1984. pp. 197222.

${ }^{4}$ Dentre os inúmeros exemplos dessa forma de representação simbólica da realeza francesa no período, destacamos o pequeno livro de emblemas do jesuíta Pierre Le Moyne (1602-1671), De l'art de regner au Roy, impresso em Paris, por Sebastien Cramoisy, em 1665. Ver ainda: KANTOROWICZ, Ernest H. Le lever du roi. Paris: B ayadrd, 2004. p. 103-133.

${ }^{5}$ Uma curiosidade sobre essa sentença escrita por Fajardo ao final da Empresa 50, cuja passagem completa é: "No acaso está em manos de validos el manejo de Europa. Quiera Dios que corresponda el suceso á los deseos públicos", é que a mesma não aparece na edição de 1640 (fol. 535). Pelo que parece, foi introduzida na edição de 1642. FAJARDO, Don Diego de Saavedra. Op. cit., 1642, fol. 363.

${ }^{6}$ Idem. Op. cit. fol. 519.

${ }^{7}$ Em suas aulas proferidas no Collège de France entre 1977 e 1978, Michel Foucault já havia observado que a superação da noção de regimen medieval - tradução da idéia de bom governo - e a afirmação da idéia de Razão de Estado foram fenômenos decisivos para o novo sentido que a política, enquanto domínio específico do cálculo, controle e coerção, sentidos que passaria a ter na modernidade. Mais recentemente, as investigações de Maurizio Viroli, Richard Tuck e Michel Senellart - este seguindo de perto as indicações de Foucault convergem no sentido de que compreendem esse período como o instante em que se operou uma profunda transformação no pensamento e na própria linguagem política. $O$ abandono dos pressupostos básicos da noção medieval de política enquanto expressão da arte do bom governo e a sua transformação em arte, quase uma técnica, da racional condução dos negócios do Estado, visando à conservação e proteção do Príncipe. Conforme, sintetizou Senellart, o discurso da Razão de Estado durante século e meio refletiu o choque das idéias de Maquiavel. Por esse caminho, imaginou-se que - Príncipe dependia da dominação para garantir sua própria segurança, do governo e para assegurar a salvação pública. A política tornou-se um domínio cada vez mais monopolizado por especialistas. $O$ termo político - ou C

A política tornou-se um domínio cada vez mais monopolizado por especialistas. O termo político - ou como se falava na época, politiques expressava justamente essa nova realidade. Mais do que uma arte, era agora uma ciência, imersa em linguagem própria, marcada pela idéia 
de segredo. Do ponto de vista normativo, era a forma pela qual o Estado constituía seus mecanismos mais enraizados de organicidade. Além do conceito consagrado de Razão de Estado, surgiram e afirmaram-se idéias como "matéria de estado", "coisas de estado" e "segredos de estado", como traduções desse novo campo de especialidade. A literatura sobre a arte de governar passava a refletir essa virada. Neste sentido, as idéias legitimadoras da privanza relacionam-se intrinsecamente com o próprio processo de racionalização e secularização da política ocorrida durante este período, em que Il Principe de Maquiavel representa verdadeira ruptura com a tradição do pensamento medieval cujos pressupostos do tomismo eram hegemônicos. Em que pese todo o repúdio e ordem de críticas que a obra de Maquiavel conheceu na Península Ibérica, as alternativas encontradas pelos pensadores católicos, marcadas pelo realismo político, inscritas na doutrina da verdadeira ou boa razão de estado, na influencia decisiva das obras de Tácito e no estoicismo, forneceram elementos teóricos que corroboraram de forma notável as teses que defendiam a presença dos validos, à sombra do rei, como "profissionais" da arte de governar. A racionalização da política enquanto técnica de comportamento e boa conduta para governantes e governados casava-se bem com os ensinamentos de Tácito, cuja compreensão que tinha da história como campo de investigação e comprovação psicologia humana, ao invés de um mero exercício de retórica. Ver: FERNÁNDEZ-SANTAMARIA, José A. Razón de Estado y política en el pensamiento español del barroco (1595-1640). Madrid: Centro de Estudios Constitucionales, 1986. FOUCAULT, Michel. Segurança, Território, População. São Paulo: Martins Fontes, 2006. MARAVALL, José António. Teoria española del Estado en el siglo XVII. Op.cit. POCOCK, John. The Machiavellian Moment. Florentine Politcal Thought and the Atlantic Republican Tradition. Princeton University Press, 1975. SENELLART, Michel. As Artes de Governar. São Paulo: Ed. 34, 2006. SKINNER, Quentin. As Fundações do Pensamento Político Moderno. São Paulo: Cia. das Letras, 1994._. Maquiavelo. Madrid: Alianza Editorial, 1998. TUCK, Richard. Philosophy and Government 1572-1651 (Ideas in Context). Nova York: Cambridge University Press, 1993. VIROLI, Mauricio. From Politics to reason of State. The acquisition and transformation of the language of politics. 1250-1600. New York: Cambridge University Press, 1992. RUBINSTEIN, Nicolai. "The history of the word politicus in early-modern Europe". In: PAGDEN, Anthony 
(coord.). The language of theory in Early-Modern Europe. New York: Cambrige University Press, 1990. pp. 41-56.

${ }^{8}$ BACON, Francis. "Essay, Civil and Moral". In: The Havard Classics. (1 ${ }^{a}$. edição 1625) New York: P. F. Collie \& Son Corporation, 1969. pp. 9394.

9 Dentre inúmeras possibilidades, destacamos autores como Ben Jonson, Francisco de Quevedo, Pedro Calderon de la Barca, Lope de Veja, Mira de Amescua, Tirso de Molina, dentre outros. Sobre essa questão, ver: CAUVIN, Mary Austin. The Comedia de Privanza in the Sevenenteenth Century. Pennsylvania: University of Pennsylvania. 1957. WORDEN, Blair. "Favoritos en la Escena Inglesa". In: ELLIOTT, John, BROCKLISS, Laurence (org.). El Mundo de los Validos. Madrid: Taurus, 1999. pp. 229-264.VALLS, TERESA FERRER. "El duque de Lerma y la corte virreinal en Valencia: fiestas, literatura y promoción social. El Prado de Valencia, de Gaspar Mercader". In: Quaderns de Filologia. Estudis literaris, V, Homenaje a César Simón, València, Facultat de Filologia-Universitat de València, 2000, pp. 257-71.

"El juego del poder: Lope de Vega y los dramas de la privanza". In: Seminario Internacional Modelos de vida en la España del Siglo del Oro. I. El Noble, 23-24 de abril de 2001. Madrid, Casa Velazquez, 2004. pp. 15-30. SHANNON, Laurie. Sovereign Amity. Figures of Friendship in Shakespearean Contexts. Chicago \& Londres: The University Chicago Press, 2002. PERRY, Curtis. Literature and favoritism in Early Modern England. New York: Cambridge, 2006.

10 A efeito de exemplificação, destacamos os seguintes autores: Francisco de Monzom, Fray Antonio de Guevara, Giovanni Botero, Andrés Mendo, Justus Lipsius, Pe. Juan de Mariana, Pe. Pedro Ribadeneyra, Bartolomeu Filipe, Diego de Saavedra Fajardo, Pe. Juan de Santa Maria, Francisco Quevedo, Tirso de Molina, Luis Vélez de Guevara, Lope de Vega, Antonio Mira de Amescua, Calderón de la Barca, Juan Perez de Montabán, Fr. José Laynez, Virgílio Malvezzi, Pe. Enrique Mendonza, Gaspar Agustín Lara, José Pellicer de Ossau Salas y Tovar, Pe. Juan Eusébio Nieremberg, Sebatião César de Meneses, Bartholomeu Pacham, Diego Ortuñes, Pedro de Navarra y de la Cueva, Diego Enriquez de Villegas. Na obra de todos esses letrados é possível encontrarmos a temática do valimento como problemática relevante.

${ }^{11}$ PORTOCARRERO Y GUZMÁN, Pedro. Teatro Monárquico de España. (1 ${ }^{a}$. Ed. 1700). Madrid: Centro de Estúdios Políticos y Constitucionales, 1998. p. 303. A historiografia sobre o tema do valimento é bastante significativa nas línguas espanhola, inglesa, italiana e francesa. 
Indicamos as principais referências: ADAMS, Simon. Leicester and the Court: Essays on Elizabethan Politics. Manchester: Manchester University Press, 2002. BELLANY, Alastair. The Politics of Court Scandal in Early Modern England: News Cultures and the Overtury Affair, 1603-1660. Cambridge: Cambridge University Press, 2002. BANNASSAR, Bartolomé. "La théorie de la monarchie dans L'Espagne du Siècle d'Or et son adaptation au système du Valido". In: LADURIE, Emmanuel Le Roy (dir.). Les Monarchies. Paris: PUF, 1986. pp. 62-71. BENIGNO, Francesco. L'Ombra del Re. Ministri e Lota Política nella Spagna del Seicento. Venezia: Marsilio Editori, 1992. BERENGER, Jean. "Por une enquete europeenne: le probleme du ministeriat au XVIIe. Siécle". In: Annales, 29, 1974. pp. 166-192. BOYDEN, James M. The Courtier and the King. Ruy Gómez de Silva, Philip II, and the Court of Spain. Berkeley/Los Angels/London: University of California Press, 1995. CALDERON ORTEGA, J. M. Alvaro de Luna: riqueza y poder en la Castilla del siglo XV. Madrid: 1998. ELLIOTT, J. H. El Conde-Duque de Olivares. El Político en una Época de Decadencia. Barcelona: Grijalbo Mondadori, 1998. . Richelieu y Olivares. Barcelona: Crítica, 2002.

\& BROCKLIS, Laurence. El Mundo de los Validos. Op. cit. ESCUDERO, José Antonio (Coord.). Los Validos. Madrid: Editorial Dykinson, 2004. FEROS, Antonio. El Duque de Lerma. Realeza y Privanza en la España de Felipe III. Madrid: Macial Pons, 2002. HAMMER, Paul E. J. The polarization of Elizabethan Politics: The Political Career of Robert Devereux, $2^{\text {nd }}$ Earl of Essex, 1585-1597. Cambridge: Cambridge University Press, 1996. LOCKYER, Roger. Buckingham: The Life and Political Career of George Villiers, First Duke of Buckingham, 1592-1628. Londres: Longman, 1981. MARAVALL, José António. Teoria española del Estado en el siglo XVII. Op.cit. MOUSNIER, Roland. La venalité des offices en France sous Henry IV et Louis XIII. Paris: Puf, 1971. OLIVEIRA, Ricardo de. "Valimento, privança e favoritismo: aspectos da teoria e cultura política do Antigo Regime". In: Revista Brasileira de História. São Paulo: ANPUH Nacional, V. 25, No. 50, Agosto-Dezembro, 2005. pp. 217-238. .Amor, Amizade e Valimento na Linguagem Cortesã do Antigo Regime". Revista Tempo. Niterói: UFF - Programa de Pós-Graduação em História, Vol. 11, no. 21, Jul-Dez 2006. pp. 109-132. PECK, Linda Levi. Court and Corruption in the Early Stuart England. London: Routledge, 1993. ROUND, Nicholas. The Greatest Man uncrowned. A Study of the fall of don Alvaro de Luna. Londres: 1986. TOMAS Y VALIENTE, Francisco. Los Validos en la 
Monarquia Española del Siglo XVII. Madrid: Instituto de Estúdios Políticos, 1963.

${ }^{12} \mathrm{O}$ entendimento que se tinha na época sobre o que era virtude fundamentava-se na autoridade tanto de autores pagãos da antiguidade clássica quanto da Bíblia e dos doutores da Igreja Medieval cristã. Como é sabido, Platão estabeleceu as quatro virtudes cardinais: prudência, justiça, fortaleza e temperança. Não obstante, segundo Aristóteles, a virtude é um hábito, uma busca pelo justo meio, uma qualidade que depende de nossa vontade, consistindo neste meio que faz relação conosco e que está regulado pela razão na forma em que o regularia o verdadeiro sábio. A virtude era o que caracterizava o homem. O filósofo, por sua vez, distinguira as virtudes em éticas (morais): liberalidade e moderação; e dianoéticas (intelectuais): sabedoria, inteligência e prudência. Cícero, no principio da obra De Officis, adicionou outras pensadas como propriamente principescas, como honestidade e honra e, como falamos, Sêneca introduziu a virtude da constância como forma de se atingir uma conduta reta e feliz. A essas, o cristianismo medieval, através das obras de Santo Agostinho e Santo Tomás de Aquino, adicionou as chamadas virtudes essencialmente cristãs: fé, caridade e esperança, virtudes que permitiriam ao homem percorrer o caminho para Deus. Em suma, é a partir desse quadro referencial que autores aqui analisados imaginaram o perfeito privado.

${ }^{13}$ LANCINA, Juan Alfonso de. Comentarios Políticos a Tácito. (1a. ed. 1687). Madrid: Centro de Estudios Políticos y Constitucionales, 2004. p. 57.

${ }^{14}$ GUEVARA, Fray Antonio de. Libro Llamado Aviso de Privados. Anueres: Matin Nucio, 1545.

${ }^{15}$ CASTIGLIONE, Baldassare. O Cortesão. (1 ${ }^{a}$. Edição 1528) São Paulo: Martins Fontes, 1997.

${ }^{16}$ DELLA CASA, Giovanni. Galateo ou Dos Costumes. (1ª. edição 1558). São Paulo: Martins Fontes, 1999.

17 Ver: CLAVERO, Barolomé. Antidora. Antropologia Catolica de la Economia Moderna. Milão: 1991.

${ }^{18}$ MERCADO, Tomás de. Suma de Tratos y Contratos. (1 ${ }^{a}$. edição 1569). Sevilla: 1571. Apud. CLAVERO, Bartolomé. Op. cit. p. 117.

19 ZAPATA, Luís. Miscelánea o Varia Historia. Santiago/Llerena: Editores Extremeños, 1999. pp. 142-143.

${ }^{20}$ CAMOS, Fray Marco Antonio. Microcosmia y Gobierno Universal del hombre Christiano, para todos los estados y qualquier de ellos. Barcelona: Imp. Pablo Malo, 1592. fol. 120. 
${ }^{21}$ Ver: RIBADENEYRA, Pe. Pedro de. Tratado de la Religión y Virtudes que debe tener el Príncipe Cristiano para gobernar y conservar sus Estados. Contra lo que Nicolas Maquiavelo y los políticos de este tiempo enseñan. Madrid: P. Madrigal, 1595. MARIANA, Pe. Juan de. "Del Rey y de la Institucion Real". (1 ${ }^{\text {a }}$. ed. 1599) In: Obras. Madrid: BAE, Vol II, 1950. SANTA MARIA, Fray Juan de. Republica y Policia Christiana. Lisboa: S.I, 1621. Sobre a imagem negativa do valimento, indicamos: FEROS, Antonio. "Imagenes de Maldad, Imagenes de Reyes: Visiones del Favorito Real y el Primer Ministro en La Literatura Política de la Europa Moderna". In: ELLIOTT, John, BROCKLISS, Laurence (org.). El Mundo de los Validos. Op. cit. pp. 293-320.

${ }^{22}$ Ver: FEROS, Antonio. El Duque de Lerma. Realeza y Privanza en la España de Felipe III. Op. cit.

${ }^{23}$ Ver: ELLIOTT, J. H. El Conde-Duque de Olivares. El Político en una Época de Decadencia. Op. cit.

24 A partir da obra Die Fürstenspiegel des hohen und Späten Mittelaltersers, de Wilhelm Berges, publicada em 1938, adotou-se a fórmula de Espelho de Príncipes para caracterizar toda a parenética régia. Os Espelhos de Príncipe estruturavam-se em torno de argumentos prescritivos sobre como deveria ser a educação para a formação do bom governante, para que praticasse a justiça, o bem comum e protegesse a sociedade. Conforme demonstrou Michel Senellart, todo pensamento medieval, a partir de Santo Agostinho, foi atravessado pela oposição entre regere (dirigir, governar, comandar) e dominatio (dominar), que subjaz à antítese do rex e do tirano. Nesse sentido, os Espelhos de Príncipe pretendiam colaborar na formação de reis que, como preconizava Isidoro de Sevilha (560-636), em suas Etimologias, "ser rei era reger" (rex a regendo), isto é, por agir corretamente. Até o século XVI, todos os livros sobre as artes de governar tiveram a forma de espelhos - speculum. No fim do séc o bem comum ulo XII, aparece o primeiro tratado sobre o governo com o nome de espelho, o Speculum Regale de Godofredo de Viterbo (1180-1183). As obras de Antonio Guevara, Francisco de Monzón, Geronimo Osório, Juan de Mariana, Pedro de Ribadeneyra que, dentre outros, produziram os mais expressivos exemplos do gênero na Península Ibérica. Ver: MARAVALL, José Antonio. Teoria del Estado. Op. cit. SENELLART, Michel. Op. cit.

${ }^{25}$ Ver: AQUINO, Santo Tomás. Da Monarquia. Madrid: Tecnos, 1996. ROMANO, Egidio. Regiment dels princips. Barcelona: Johan Luschner, 1498. (Ed. Facsímil). GALLINO CARRILO, Maria Angeles. Los Tratados 
Sobre Educacion de Principes. Siglos XVI y XVII. Madrid: Consejo Superior de Investigaciones Cientificas, 1948. BUESCO, Ana Isabel. Imagens do Príncipe. Discurso Normativo e Representação (1525-49). Lisboa: Edições Cosmos, 1996.

${ }^{26}$ Ver: MARAÑGON, Gregorio. Antonio Perez. Madrid: Espasa-Calpe, 2006.

${ }^{27}$ PÉREZ, Antonio. "A un Gran Privado". In: Relaciones y Cartas. Madrid: Turner, Vol. II, 1986. pp. 77-80.

${ }^{28}$ Ver: BOUZA, Fernando. Corre Manuscrito. Una Historia Cultural Del Siglo de Oro. Madrid: Marcial Pons, 2001.

${ }^{29}$ FEROS, Antonio. "El Duque de Lerma: Valimiento y construcción de un nuevo paradigma político". In: ESCUDERO, José Antonio (org.). Op. cit. p. 77.

${ }^{30}$ MALDONADO, Fray Pedro de. Discurso del Perfecto Privado. BNM. MSS 18721/48. Apud. FEROS, Antonio. Op. cit. p. 77.

${ }^{31}$ Ver: OUEVEDO Y VILLEGAS, Don Francisco de. "Cómo ha de ser el Privado". In: Obras Completas de Don Francisco de Quevedo y Villegas Obras en Verso. Madrid: Aguilar, Tomo II, 1988. pp. 592-635.Ver: SOMERS, Melvina. "Quevedo's Ideology in Cómo ha de ser el privado". In: Hispania, Vol. 39, No. 3, Sep., 1956. pp. 261-268.

${ }^{32}$ QUEVEDO Y VILLEGAS, Don Francisco de. Discurso de las Privanzas. Navarra: Ediciones Universidad de Navarra, 2000. p. 211

${ }^{33}$ Ver: QUEVEDO Y VILLEGAS, Don Francisco de. "Grandes Anales de Quince Dias". In: Obras Completas de Don Francisco de Quevedo y Villegas - Obras en Prosa. Madrid: Aguilar, 1941. pp. 565-595.

${ }^{34}$ Ver: FERNNANDEZ-SANTAMARIA, José A. Op. cit.

${ }^{35}$ Ver: QUEVEDO Y VILLEGAS, Don Francisco de. "Política de Dios, Gobierno de Cristo y Tirania de Satanás". In: Op. cit. pp. 360-535.

${ }^{36}$ Ver: MATTHIEU, Pierre. Historia del dichoso desdichado. Madrid: Pedro Tazo, 1625. ___. Historia de la prosperidad infeliz de Felipa Caetana, la lavandera de Nápoles. Madrid: Diego Flamenco, 1625. . Historia de las guerras de Flandes, contra la de Geronimo de Franqui Conestaggio, escrita en frances por Pedro Matheo ; y en castellano por Iuan Pablo Martyr Rizo. Valencia: Patricio Mey, 1627. . Historia de la muerte de Enrico el Grande, cuarto Rey de Francia de este nobre, traducida del frances al castellano por Juan Pablo Martir Rizo. Segovia: por Diego Flamenco, 1628.

${ }^{37}$ RIZO, Juan Pablo Mártir. Norte de Príncipes y Vida de Romulo. Madrid: Centro de Estudios Constitucionales, 1988. p. 63.

${ }^{38}$ Idem. Op. cit. pp. 63-64. 
${ }^{39}$ Idem. Op. cit. p. 64.

${ }^{40}$ Idem. Op. cit. p. 64.

${ }^{41}$ Covarrubias, em seu Tesoro, registrara que o prudente é o "hombre sábio y reportado, que pesa todas las cosas con mucho acuerdo, prudens". COVARRUBIAS Y HOROZCO, Sebastian de. Op. cit. p. 885. No Vocabulário de Bluteau, temos talvez a melhor compreensão coetânea acerca do conceito, assinalando que, no alvorecer do setecentos, em Portugal, e isso vale também para a Espanha, considerava-se prudência como o meio através do qual era possível impedir o dano, ou seja, evitar que problemas acontecessem, assim, era a prudência a principal: " virtude intelectual, que ensina ao homem o reto modo de obrar, e o que e moralmente bom, ou mal, para abraçar ou fugir. $E$ a primeira das virtudes cardinais, e se divide em política, economia e monástica. A prudência política tem por objetivo o bem publico por meio da observância das leis humanas e divinas. A prudência econômica atende ao bem da família, e a prudência monástica ao bem do individuo, buscando uma e outra vias justas, úteis e honestas, e fugindo a seus contrários". BLUTEAU, Pe. Raphael. Vocabulário Português \& Latino. Coimbra: Colégio das Artes da Companhia de Jesus, Tomo VII,1712-1728. p. 811. A ordem em que foram publicadas as diversas partes da obra e a seguinte: os tomos I (letra A) e II (letras B e C) foram publicados em 1712, os tomo III (letras (letras D e E), IV ( $\mathrm{F}$ e G) e V (H e J) em 1713, o tomo VI (letras K, L, M e ), em 1716, o tomo VII (letras O e P), em 1720, o tomo VIII (letras K, R e S), em 1720, o tomo IX (letras T, U, V, X e Z - há ainda neste último tomo um pequeno dicionário castelhano - português também de autoria do Pe. Bluteau), em 1721, e, por fim, o tomo X, em 1728, que compreende um suplemento.

${ }^{42}$ Ver: RIZO, Juan Pablo Mártir. Historia de la vida de Lucio Anneo Séneca Español. Madrid: Juan Delgado, 1625.

${ }^{43}$ Ver: RIZO, Juan Pablo Mártir. Historia de la vida de Mecenas. Madrid: Diego Flamenco, 1625.

${ }^{44}$ Ver: MARAVALL, José Antonio. "Juan Pablo Martir Rizo: Estudio Preliminar a una Edicion de sus obras". In: Estudios de Historia del Pensamiento Español. Serie Tercera - El Siglo del Barroco. Madrid: Ediciones Cultura Hispanica, 1984. pp. 418 e segs.

${ }^{45}$ Idem. p. 420.

${ }^{46}$ Inúmeros autores compartilharam dessa mesma opinião naquela época. Elemento chave no ideário humanista, tornou-se verdadeiro lugar comum entre os pensadores que se detinham em refletir sobre o 
universo da política a crença na capacidade da "pedagogia" construir o bom governante. Não é por acaso que o gênero do Specula Princips conheceu enorme profusão nos séculos XVI e XVII, principalmente com as obras de Antonio Guevara, Francisco de Monzón, Geronimo Osório, Juan de Mariana, Pedro de Ribadaneira que, dentre outros, produziram os mais expressivos exemplos do gênero na Península Ibérica quinhentista. Em todos esses autores, podemos encontrar uma defesa dessa tese. Além disso, como sustenta Maravall, podemos crer que a totalidade da literatura política, não somente a escrita especular, possuía em sua essência uma intencionaldade pedagógica. Para ficarmos em mais um exemplo, poucos anos depois, o desconcertante Diego Enriquez de Villegas, das personagens mais interessantes e desconhecidas das letras luso-espanholas do seiscentos, no espelho El Príncipe en la Idea, reiterava a questão revestindo-a de uma importância especial, pois era a educação "llave del bien, y del mal es la primera educaion: puede mas que la misma naturaleza; pues, enmienda, repara, y corrige sus faltas..". Neste sentido, "...en todos casos el amor, y temor de Dios, la justicia, prudencia, vigiancia, entereza, juizio, clemencia, equidade, templança, comprehension, liberalidad, y noticias habilitan para la púrpura... desean los soberanos tener hijos (natural afecto) para que sucedan em la grandeza que heredaron; que adquirieron; teniendolos; conviene, , desde la puerícia, dirigir, por la ensenãnça, sus passos..." VILLEGAS, Diego Enriquez de. El Príncipe en la Idea. Madrid: Imprensa Real, 1656. fol. 17, 29-30.

${ }^{47}$ RIZO, Juan Pablo Mártir. Historia de la vida de Lucio Anneo Séneca Español. Op. cit. fol. 83

${ }^{48}$ Ver: RIZO, Juan Pablo Mártir. Historia trágica de la vida del duque de Birón. Barcelona: Sebatián de Cormellas, 1625.

49 Essa obra não chegou a ser impressa, apesar das licenças para publicação terem sido dadas. Os manuscritos originais encontram-se guardados na Biblioteca Colombina.

${ }^{50}$ ROBLES, Juan de (1574-1649). Tardes de Alcázar. Doctrina Para el Perfecto Vassalo. Sevilla: Excma. Diputación Provincial Patronato de Cultura, 1948. p. 95.

${ }^{51}$ Idem. p. 95.

${ }^{52}$ Idem. p. 96.

${ }^{53}$ Idem. pp. 96-97.

${ }^{54}$ Idem. p. 97.

${ }^{55}$ Idem. p. 97. 
${ }^{56}$ Ver: PELLICER DE OSSAU Y TOVAR, José. La Constancia christiana, necessária a um valido. Madrid: Viuda de Alonso Martin, 1638.

${ }^{57}$ Ver: LIPSIUS, Justus. Libro de la Constancia. Sevilla: M. Clauijo, 1616.

${ }^{58}$ LAYNEZ, Fray José. El Privado Christiano, deducido de las vidas de Joseph y Daniel, que furem balanzas de los Validos en el fiel contraste del pueblo de Dios. Madrid: Juan de Noots, 1641. fol. 25

${ }^{59}$ Idem. Op. cit. fol. 26.

${ }^{60}$ ORTEGA Y ROBLES, Gerónimo. El despertador que avisa a un Príncipe católico, ya de las inquietudes de la guerra y ya de los sosiegos de la paz. Hecho de la vida del Emperador Constante. Madrid: Julián de Paredes, 1647. fol. 11.

${ }^{61}$ Idem. Op. cit. fol. 11.

${ }^{62}$ HERRERA, Pedro Martinez. El Príncipe ardvertido y declaración de epigramas de Nápoles la vispera de San Juan. Nápoles: L. Sconggio, 1631. fols. 83-84.

${ }^{63}$ MUT, Vicent. El Príncipe en la Guerra y en la paz, copiado de la vida del Emperador Justiniano. Madrid: Juan Sánchez, 1621. fol. 10

${ }^{64}$ Idem. Op. cit. fols. 11 e 12.

${ }^{65}$ Idem. Op. cit. fol. 139.

${ }^{66}$ ORTEGA Y ROBLES, Gerónimo. Op. cit. fol. 12.

67 MALLEA, Fray Salvador. Rey Pacífico y Gobierno del Príncipe Católico. Gênova: Pedro Francisco Barberio, 1646.

${ }^{68}$ FAJARDO, Don Diego de Saavedra. Op. cit. fol. 512.

${ }^{69}$ Idem. Op. cit. fols. 512-513.

${ }^{70}$ Idem. Op. cit. fol. 513. Fajardo, para reforçar esse pressuposto do valimento, recorreu à autoridade do Rei Don Alonso, o sábio, que em passagem de suas Partidas afirmava: "non podria ver, nin librar, a todas las cosas, porque è menester por fuerza ayuda de otros, en quien se fiè, que cumplan, en su lugar, usando del poder, que del reciben en aquellas cosas, que el non propria por si cumplir." Las Siete Partidas del Rey Afonso el Nono, nuevamente Glosadas por el Licenciado Gregório Lopez del Consejo Real de Índias de Su Magestad. Impresso em Salamanca, Andréa Portonaris, Impressor de Su Magestad. Año MDLV (1555). (Ed. Fac-similar). L. 3, II, fol. 2.

${ }^{71}$ OLVEIRA, Ricardo de. "Amor, Amizade e Valimento na Linguagem Cortesã do Antigo Regime". Tempo. Niterói: UFF - Programa de PósGraduação em História, Vol. 11, no. 21, Jul-Dez 2006. pp. 109-132.

72 TUCK, Richard. Op. cit.

${ }^{73}$ FAJARDO, Diego Saavedra. Op. cit. fol. 514.

${ }^{74}$ Idem. fols. 515-516. 
${ }^{75}$ Idem. fol. 514.

${ }^{76}$ Idem. fol. 514.

${ }_{77}^{7 d}$ Idem. fol. 517.

${ }^{78}$ A obra de Juan de Solorzano Pereira, Emblemata Regio-Politica in centuriam unam atque illustrata, foi originalmente impressa em Madrid, por Dominus Garcia Moras, no ano 1651, e exerceu um destacado papel tanto no campo da literatura de emblemas, quanto no âmbito dos specula princips da Espanha do século XVII. Ainda nesta década, entre os anos de 1658-1660, o impressor Bernardo Nogués publicou a tradução castelhana dessa obra, realizada por Loureço Matheu y Sanz, dividida em 10 volumes, cada volume ilustrado com 10 emblemas.

79 SOLÒRZANO PEREIRA, Juan de. Emblemata Regio-Politica in centuriam unam atque illustrata. Matrit: Dominus Garcia Moras, 1651. fol. 469.

80 Exemplo disso pode-se perceber analisando o emblema LVII, cujo mote é Qui eminent, cadunt, e tem um personagem cuja cabeça supera as nuvens, provocando a ira dos seus. Essa representação remete-nos à circunstância retratada na mitologia clássica relacionada à luta entre os gigantes e os Deuses. Essa questão aparece em Homero, no livro V da Ilíada e no livro XI da Odisséia, Apolodoro, Plutarco, Marcelo, Virgílio e Ovídio. Resumidamente, a passagem mítica é a seguinte: os gigantes Efialte e Oto, filhos de Posseidón e Ifimedea, que a cada ano cresciam mais e mais, resolveram se rebelar contra os Deuses. Em represália, Zeus (Júpiter) destruiu-os com seus raios. A literatura emblemática se apropriou dessa imagem para condenar aos que queriam se comparar aos Príncipes, pois, tal como os gigantes Efialte e Oto, quem ousasse fazê-lo seria destruído. Dessa forma, Solòrzano compara a ambição dos gigantes ao desejo de poder que orientaria a trajetória dos validos. Ver: GONZALEZ DE ZARATE, Jesus Maria. Emblemas Regio-Politicos de Juan de Solorzano Pereira. Madrid: Ediciones Tuero, 1987. pp. 167-168.

${ }^{81}$ MENDO, Padre Andrés. Príncipe Perfecto Y Ministros Aiustados, Documentos Políticos, Y Morales. En Emblemas. Lyon: Horacio Boissat y George Remeus, 1662. fol. 38. Na "editio princeps", de Lyon, 1642, e na edição de Salamanca, de 1657, só aparece o texto. A primeira edição ilustrada é a de Lyon, 1661. Consta de 80 emblemas que, conforme dissemos, foram retirados da obra de Solòrzano Pereira. Cada emblema denomina-se "documento", e segue a seguinte ordem: "pintura" e mote, 
breve glosa do mote, e explicação. Os motes estão em latim. Ao mote do emblema 72, falta o texto.

${ }^{82}$ Sobre essa questão, ver: ONCE MORE, Emilia's Guilt. "Concerning Solorzano Pereyra's Emblemata regiopolitica and Andres Mendo's Principe perfecto". In: Modern Language Notes. Londres: The Johns Hopkins University Press, Vol. 71, No. 4 , April, 1956, pp. 283-287. REY SIERRA, Ana María. "Mendo, a la sombra de Solórzano Pereira". In: POZA, Sagrario Lopez (coord.). Estudios sobre literatura emblemática española. La Rioja: Sociedad de Cultura Valle Inclán, 2000. pp. 261-271. ${ }^{83}$ Idem. fol. 39.

${ }^{84}$ Idem. fol. 39.

${ }^{85}$ Idem. fols. 40-41.

${ }^{86}$ NAVARRA Y DE LA CUEVA, Pedro de. Logros de la Monarquia en aciertos de un valido. Madrid: I. de Paredes, 1669. fol. 1.

${ }^{87}$ Idem. fol. 1.

${ }^{88}$ Idem. fol. 2.

${ }^{89}$ BAÑOS DE VELASCO, Juan. Lanneo Seneca ilostrado en blasones politicos j morales... . Madrid: s.n. 1670.

${ }^{90}$ BAÑOS DE VELASCO, Juan. El sabio en la pobreza, commentarios estoycos, $j$ historicos a Seneca. Madrid: Francisco Sanz, 1671.

${ }^{91}$ BAÑOS DE VELASCO, Juan. El ayo y maestro de principes Seneca en su vida. Madrid: Francisco Sanz, 1674.

${ }^{92}$ LARA, Gaspar Augustin. Equilíbrio Christiano político y moral que pondera, proporciona y mide los passos Del primer Ministro por el árduo camino de la Privança para sentarlos firmes y conducirlos seguros al encubrado logro de la Monarquia del Mayor Monarcha de dos Mundos D. Carlos Segundo de Nustria em los aciertos de su digníssimo valido. Madrid: Mechor Alvarez, 1680.

${ }_{93}$ MENDONZA, Fray Henrique de. Documentos y avisos necesarios a vien vistos y favorecidos Príncipes y Soberanos, com cuya observância llegaran a la cumbre de sus deseos, haciendo estable y perpetua su felizidad en servicio de Dios Nuestro Señor, i augmento de la Monarquia. Madrid: 1623. BNM, Ms. 8512. Apud. TOMÁSY VALIENTE, Francisco. Op. cit. p. 143.

${ }^{94}$ MALDONADO, Fray Pedro. Op. cit.

${ }^{95}$ RENZI, Mateo. El Privado Perfecto. Madrid: 1629. BNM, Ms. 5873. fols. 25-30.

${ }^{96}$ TOMÁSY VALIENTE, Francisco. Op. cit. p. 143. 


\section{RICARDO DE OLIVEIRA}

97 NAVARRETE, Pedro Fernandez de. "Lélio Peregrino a Estanislao Borbio". In: Obras del Licenciado Pedro Fernandez Navarrete. Madrid: BAE, 1947. pp. 547-557.

${ }^{98}$ SENELLART, Michel. Op. cit.

Artigo recebido em 01/2009. Aprovado em 04/2009 